\title{
SÍŤOVÁ ANALÝZA V PRÁVU: SÍŤOVÉ METODY A JEJICH VYUŽITÍ PRO ZÍSKÁVÁNÍ A VYHLEDÁVÁNÍ PRÁVNÍCH INFORMACÍ ${ }^{1}$
}

\author{
TEREZA NOVOTNÁ ${ }^{2}$
}

\begin{abstract}
ABSTRAKT
Tento článek si dává za cil přinést přehled využití metod sítové analýzy $v$ právu a diskutovat využití těchto metod pro vyhledávání právních informací. Za tímto účelem obsahuje teoretický základ fungování sítové analýzy, těžiště článku však leži spíše v kategorizaci způsobů využití této metody při aplikaci na právní prameny. Účelem prehledu je pak zdůraznit odlišnosti této metody od ostatních statistických metod a zejména vyzdvihnout její výhody. Na základě těchto závěrů pak autorka diskutuje vhodnost využití sítových metod pro jednodušši a obecně př́stupnějši vyhledávání právních informací a navrhuje některé konkrétní metody, jak by sítová analýza mohla pomoct v práci s právními informacemi.
\end{abstract}

\section{KLÍČOVÁ SLOVA}

Sítová analýza; vyhledávání právních informací; statistické metody v právu; vizualizace právních informací

Tento článek vznikl na Masarykově univerzitě v rámci projektu "Právo a technologie IX" číslo MUNI/A/1292/2020 podpořeného z prostředků účelové podpory na specifický vysokoškolský výzkum, kterou poskytlo MŠMT v roce 2021.

2 Mgr. Tereza Novotná je interní doktorandkou na Ústavu práva a technologií Právnické fakulty Masarykovy univerzity. Kontaktní e-mail je: tereza.novotna@mail.muni.cz 


\begin{abstract}
This article aims to provide an overview of the use of network analysis methods in law and to discuss the use of these methods for legal information retrieval. For this purpose, it contains the theoretical basis for the functioning of network analysis, but the focus of the article lies more in the categorization of ways of using this method in the application to legal sources. The purpose of the overview is to emphasize the differences of this method from other statistical methods and especially to highlight its advantages. Based on these conclusions, the author discusses the suitability of using network methods for easier and more generally accessible legal information retrieval and suggests some specific methods of how network analysis could help in working with legal information.
\end{abstract}

\title{
KEYWORDS
}

Network Analysis; Legal Information Searching; Statistical Methods in Law; Visualization of Legal Information

\section{1. ÚVOD A MOTIVACE}

Právo je pravděpodobně jedním z nejnáročnějších profesních odvětví z pohledu množství informací, které obsahuje. ${ }^{3}$ Množství právních pramenů, jejichž obsah označujeme pojmem „právo“, je dnes již pro člověka analogicky neobsáhnutelným objemem informací, pro jejichž faktické poznání společnost již téměř výhradně využívá informačních technologií a digitálních formátů, a to i přesto, že podpora těchto technologií někdy vychází pouze ze soukromé sféry a stát $\mathrm{v}$ tomto směru zaostává. Společnost 21. století spoléhá už jen na právo, ke kterému přistupuje s využitím informačních technologií, a to na škále od fundamentálního vyhledání obsahu konkrétního zákonného ustanovení v (at již soukromém či v lepším případě veřejném) právním informačním systému po sofistikovanější tvorbu rešerší a právních analýz a právních názorů závislých na vyjma legislativních pramenů také související judikatuře, ale i přidružené komentářové či odborné

3 SUSSKIND, Richard E. The Future of Law: Facing the Challenges of Information Technology. Oxford: Clarendon Press, 1998, s. 79. 
literatuře a další řadě podpůrných materiálů od důvodových zpráv po vzorové typy smluvních ustanovení. S rozvojem informačních technologií se nejen pro laickou (ve smyslu ne-právní) veřejnost stal obsah práva synonymem pro textaci legislativních ustanovení $\mathrm{v}$ některém $\mathrm{z}$ veřejně dostupných online právních informačních systémů. Z pohledu informačního objemu práva, jeho složitosti a komplexnosti $\mathrm{v}$ kombinaci s historicky bezprecedentním rozmachem obecného využití informačních technologií je toto logický a předpokládaný vývoj, nelze očekávat, že se tento trend v budoucnu zvrátí, spíše naopak - je nutné čekat spíše jeho akceleraci. Takové situaci je pak nutné se přizpůsobit a informační technologie předkládající právo společnosti vytvořit takové, aby nejenže poskytovaly správné (ve smyslu totožné s oficiálním výsledkem legislativního či jiného právotvorného procesu) právní informace, ale i v co největší možné míře př́stupné a kognitivně poznatelné pro co největší část společnosti, čímž by byla naplněna základní informační potřeba společnosti ohledně poznání obsahu práva, které je povinna dodržovat. ${ }^{4}$ Metodologické oddělení těchto dvou podmínek - 1) správnosti a 2) př́stupnosti a kognitivní poznatelnosti ${ }^{5}$ - je důležité zejména s ohledem na požadavky, které klademe na konkrétní metody zpracovávání a vyhledávání právních informací, a které budou rozebrány níže $\mathrm{v}$ textu.

Výše popsané aktivity lze shrnout pod obecně používaný pojem „vyhledávání právních informaci“" (či „získávání právních informaci“", překlad z anglického termínu „legal information retrieval“), který je podřazen obecnému termínu „vyhledávání informaci“ (v anglickém originále „information retrieval"), který se vyvinul spolu s rozvojem informačních technologií a internetu, poskytujícího dříve nepředstavitelné množství informací a dat. Taková situace způsobila zásadní obrat ve způsobu, jakým obecně lidé poznávají svět. Proces vyhledávání a získávání informací, které potřebujeme, se stává minimálně stejně důležitým jako je samotná informace o světě.

4 O požadavcích kladených konkrétně na promulgaci práva viz např.: POLČÁK, Radim. Internet a proměny práva. 1. vyd. Praha: Auditorium, 2012, s. 204 a 209, citující Benthama.

5 Kognitivní poznatelností práva a vztahem k právním informačním systémům se zabývá např. ASHLEY, Kevin D. Artificial Intelligence and Legal Analytics: New Tools for Law Practice in the Digital Age. Cambridge: Cambridge University Press, 2017. 
Zvýšena pozornost věnovaná tomuto procesu pak způsobuje vznik vyhledávání informací jako samostatného odvětví informační vědy.

Navážeme-li na rozdělení podmínek správnosti a př́istupnosti a kognitivní poznatelnosti právních informací, poté první podmínka správnosti znamená samotnou existenci a přítomnost právní informace v systému či databázi obecně a její objektivní správnost, tedy shodnost obsahu s příslušnou autoritou vytvořeným obsahem, a druhá podmínka pak znamená možnost tuto informaci najít a zjistit její obsah a to včetně možnosti ji kognitivně poznat a pochopit v kontextu. Vyhledávání právních informací, jak je patrné, se pak zabývá zejména, avšak nevýhradně, splněním podmínky druhé. Současně je ale splnění podmínky první, tedy existence a správnosti právní informace, nezbytné pro její vyhledání a poznání. Tyto dvě podmínky jsou tedy nutně vzájemně závislé. ${ }^{6}$

Jak uvádí Malmgren ${ }^{7}$, možnost efektivně nacházet dokumenty (právní prameny) v systému je důležitá vlastnost systému vyhledávání informacíi, $\mathrm{z}$ tohoto důvodu je definována tzv. informační potřeba koncového uživatele, kterou tento uživatel chce $\mathrm{v}$ rámci systému vyhledávání informací uspokojit. Za tímto účelem jsou definovány různé způsoby a metody, jak v systému informace vyhledávat - nejzákladnější rozdělení je vyhledávání pomocí uživatelského dotazu (a to jak fulltextem, tak pomocí klíčových slov atd.) nebo pomocí postupného tematického zužování hranic seznamu vyhledaných dokumentů (pod tímto způsobem si lze představit mimo jiné také vyhledávání pomocí předem určených kategorií a tříd dokumentů, kte-

6 V tomto ohledu lze zmínit výzkum Harašty, který se týká sekundárních pramenů, tedy soudních rozhodnutí, a ukazuje, že tři nejpoužívanější české právní informační systémy se velmi málo liší celkovým objemem judikatury, který obsahují, avšak výrazně se liší tím, jak tuto judikaturu zprostředkovávají k vyhledávání uživateli. Podmínku správnosti tedy splňují víceméně stejně, liší se však ve způsobech předkládání informací uživateli. Viz: HARAŠTA, Jakub. Srovnávací studie právních informačních systémů: rozdíly mezi systémy při využití různých vyhledávacích strategií. Revue pro právo a technologie. Masarykova univerzita, 2020 , roč. 11, č. 22, s. 219-260.

7 MALMGREN, Staffan. Towards a theory of jurisprudential relevance ranking. Using Link Analysis on EU Case Law. Graduate thesis, Stockholm University, 2011, s. 6.

8 Jedná se o tzv. bibliografickou relevanci dle kategorizace viz: VAN OPIJNEN, Marc a Cristiana SANTOS. On the concept of relevance in legal information retrieval. Artificial Intelligence and Law. 2017, roč. 25, č. 1, s. 71. 
ré se postupně zpřesňují). ${ }^{9}$ Cílem využití metod vyhledávání informací je poskytnout všechny výsledky, které jsou relevantní a současně navíc žádné, které relevantní nejsou. Za tímto účelem vznikly metriky vyhledávání informací, které měří právě tyto hodnoty a slouží $\mathrm{k}$ hodnocení a komparaci metod vyhledávání informací. ${ }^{10}$ Je však patrné, že samotná definice relevance vyhledané informace vůči uživatelské potřebě je náročným úkolem, protože $\mathrm{z}$ určité části bude vždy subjektivní. Přesto však vznikají studie o tom, jak relevanci chápat a měřit tak, aby byly vyhledávací metody objektivně aplikovatelné. Např́klad výše citovaní Opijnen a Santos kategorizují relevanci právních informací dle metodologie užívané pro obecné vyhledávání informací. Dle jejich kategorií se pak přirozeně liší i míra závislosti daného typu relevance na subjektivním hodnocení uživatele. ${ }^{11}$

Sítová analýza obecně je matematicko-statistickou metodou založenou na teorii grafů; tato metoda byla navrhnuta dávno před vznikem informačních technologií a internetu a nejedná se tedy o a priori metodu vyhledávání informací. ${ }^{12}$ Domnívám se ale, že pro svoje specifické vlastnosti, které budou popsány níže $\mathrm{v}$ textu, je vhodné ji jako metodu vyhledávání informací $\mathrm{v}$ určitých případech použít, protože právě díky svým specifickým charakteristikám se k některým úkonům vyhledávání (zde konkrétně) právních informací hodí více než metody standardní uvedené v předchozím odstavci. Cílem tohoto článku je poté ukázat na základě přehledu využití a řadě př́kladů, že tato metoda dokáže splnit požadavky, které klademe na metody zpracovávání a vyhledávání právních informací. Současně se pokusím ukázat, že díky některým svým specifickým charakteristikám sítová analýza splňuje podmínku snadnější přístupnosti a kognitivní poznatelnosti

9 MALMGREN, Staffan. Towards a theory of jurisprudential relevance ranking. Using Link Analysis on EU Case Law. Graduate thesis, Stockholm University, 2011, s. 7 a násl.

10 Jedná se o metriky precision a recall. Konkrétně jsou na příkladu českých právních informačních systémů popsány např. v: HARAŠTA, Jakub. Srovnávací studie právních informačních systémů: rozdíly mezi systémy při využití různých vyhledávacích strategií. Revue pro právo a technologie. Masarykova univerzita, 2020, roč. 11, č. 22, s. 225 s odkazem na: ASHLEY, Kevin. Artificial Intelligence and Legal Analytics: New Tools for Law Practice in the Digital Age. Cambridge: Cambridge University Press, 2017, s. 222.

11 VAN OPIJNEN, Marc a Cristiana SANTOS. On the concept of relevance in legal information retrieval. Artificial Intelligence and Law. 2017, roč. 25, č. 1, s. 65-87.

12 Více o vzniku a vývoji sítové analýzy v kapitole 1.2 . 
právních informací lépe než některé standardně užívané metody. Z tohoto důvodi̊ má potenciál být metodou, která bude obecně použitelná k zpřístupnění práva široké veřejnosti.

Tato práce je rozdělena do tří hlavních částí: v první kapitole bude nejprve definováno, co je to sítová analýza a jaké jsou její teoretické základy a východiska, dále bude uvedena historie a přehled využití sítové analýzy ve společenskovědních oborech. Druhá kapitola poté obsahuje přehled způsobů využití metod sítové analýzy v právu a to zejména s ohledem na využití za účelem vyhledávání právních informací. Třetí kapitola obsahuje diskuzi nad vhodností využití metod sítové analýzy pro zpracovávání a vyhledávání právních informací, jsou zde analyzovány požadavky kladené na metody vyhledávání informací tak, aby bylo možné konstatovat schopnost metody předložit právo kognitivně poznatelné a přístupné. V příkladech jsou dále navrženy některé konkrétní způsoby, jakými lze metody aplikovat tak, aby bylo možné dosáhnout tohoto cíle.

\section{SÍŤOVÁ ANALÝZA ${ }^{13}$}

Není překvapivé, že mezi kvantitativními metodami používanými ve společenských vědách sítová analýza vzbuzuje čím dál větší zájem. Oproti ostatním - statistickým - kvantitativním metodám totiž obsahuje jeden další nástavbový atribut, kterým je možnost zobrazovat a kvantifikovat nejen určité společenské jevy či entity a jejich vlastnosti, ale i vztahy mezi nimi. ${ }^{14}$ Právě tyto vztahy jsou jádrem sítové analýzy a spolu s entitami tvoří tzv. sít. Tímto způsobem sítová analýza nabízí novou úroveň zkoumání společenských jevů skrz vztahy mezi nimi a jejich kvantifikaci, a to se

${ }^{13}$ Kapitola č. 2 byla publikována v podkapitolách č. 6.3.1, 6.3.2 a 6.3.3 v části I. monografie: HARAŠTA, Jakub, Terezie SMEJKALOVÁ, Tereza NOVOTNÁ, Jaromír ŠAVELKA, Radim POLČÁK, František KASL, Pavel LOUTOCKÝ a Jakub MíŠEK. Citační analýza judikatury. 1. vydání. Praha: Wolters Kluwer, 2021. 256 s.

${ }^{14}$ DE NOOY, Wouter, Andrej MRVAR a Vladimir BATAGELJ. Exploratory Social Network Analysis with Pajek: Revised and Expanded Edition for Updated Software. 3. vyd. Cambridge: Cambridge University Press, 2018. Structural Analysis in the Social Sciences. s. 5; dále WATTS, Duncan J. Six Degress: the Science of Connected Age. New York: W. W. Norton \& Company, 2003, s. 27 a násl. a obecně také DEGENNE, Alain a Michel FORSÉ. Introducing Social Networks. London: SAGE Publications, 1999, 256 s. 
ukazuje jako směr, který přináší do aktuální odborné diskuze nová zjištění, což mu zajištuje vzrůstající popularitu. Typ zkoumaných společenských vztahů je pak velmi široký, dnešní datová analýza využívá sítové metody ke zkoumání struktur politických, ekonomických, společenských, psychologických i právních.

\subsection{CO JSOU METODY SÍŤOVÉ ANALÝZY A JAK FUNGUJÍ?}

Sítová analýza je založena na předpokladu, že pro co nejúplnější obraz o zkoumaném datasetu entit (těmi mohou být jednotliví aktéři, jako jsou politici, uživatelé sociálních médií či členové kriminálních gangů, dále např́ílad politické strany či lokální novinové deníky až po dokumenty jako jsou napřr. soudní rozhodnutí, jednotlivé zákony nebo zapsané patenty) je minimálně stejně důležitá struktura, ve které se tyto entity navzájem nacházejí a ovlivňují, jako jejich jednotlivé vlastnosti. ${ }^{15}$ Tento př́stup, ačkoliv není tak široce použitelný jako např. obecná statistika, se ukázal nejen pro vědy společenské jako přistup, který přináší mnohá nová zjištění. Tato zjištění jsou pak možná nejen z nových proměnných, které sítová analýza nabízí, ale také z grafického znázornění zkoumané struktury, které samo o sobě přináší další kognitivní vjemy při analýze společenského jevu. ${ }^{16}$ Mezi výhody, které přináší vhled na společenský jev jako na sít, patří také možnost vybrat úroveň, na které chceme daný jev pozorovat. Sítová analýza totiž díky tomu, že nabízí proměnné, na základě kterých lze pozorovat strukturu společenského jevu a tím si lze vytvořit celkový přehled, nabízí také možnosti jak pozorovat pouze část sítě či pouze jednotlivou entitu a její vztahy a tím nabízí hodnotné zázemí i pro individuálně zaměřenou kvalitativní analýzu.

Jak již bylo řečeno, sítová analýza je vhodná zejména k popisu společenského jevu jako celku se zaměřením na jeho strukturu a na vzájemné vztahy mezi jednotlivými aktéry či entitami. Podoba těchto vztahů může

15 WASSERMAN, Stanley a Katherine FAUST. Social Network Analysis: Methods and Applications. Cambridge: Cambridge University Press, 1994 s, 4-5.

${ }^{16}$ CARRINGTON, Peter J., John SCOTT a Stanley WASSERMAN, eds. Models and Methods in Social Network Analysis. Cambridge: Cambridge University Press, 2005. Structural Analysis in the Social Sciences. s. 248-251. 
být velmi široká, jedná se jakoukoliv změřitelnou či zaznamenatelnou spojitost mezi entitami. Vedle tohoto základního principu vznikla v odborné literatuře shoda na základních konceptech, které odlišují sítovou analýzu od jiných vědeckých metod použitelných ve společenských vědách. Tyto koncepty popsal už v roce 1988 Wellman. Zde jsou vybrány dva z těchto konceptů, které lze úspěšně aplikovat i na téma tohoto článku, kterým je sítová analýza v právu: (1) na entity či aktéry a jejich interakce je nahlíženo spíše jako na vzájemně závislé než nezávislé a (2) sítový model je konceptem, který zdůrazňuje strukturu jako trvalý model vztahů mezi objekty. ${ }^{17}$

\subsection{HISTORIE SÍŤOVÉ ANALÝZY}

Historické kořeny sítové analýzy a s ní související teorie grafů jsou datovány do roku 1736, kdy Leonhard Euler vyřešil matematický problém známý pod názvem Sedm mostů v Královci, což je považováno za stavební kámen teorie grafů. ${ }^{18}$ Od té doby můžeme její použití sledovat v každém oboru přírodních věd, od matematiky, která položila její základy a počítačové vědy, která zase umožnila její jednoduché použití i pro matematické laiky ${ }^{19}$, až po biologii $^{20}$, chemii $^{21}$, fyziku ${ }^{22}$ a další.

Nicméně, ve společenských vědách datujeme první použití této metody do 30. let 20. století a prvními průkopníky využití této metody bývají uvá-

17 GRANOVETTER, Mark. Social Structures: A Network Approach. In: WELLMAN, Barry a BERKOWITZ, S. D. (eds.). Structural Analysis in the Social Sciences, vol. 2. Cambridge: Cambridge University Press, 1988, s. 20.

18 BRADLEY, Robert E. a C. Edward SANDIFER. Leonhard Euler: Life, Work and Legacy. Amsterdam: Elsevier, 2007, s. 409 a násl.

19 Zejména díky dnes už dostupným softwarům (jako např. Gephi) či modulům implementovaným do programovacích jazyků (jako např. Gensim pro Python či dostupné moduly pro R).

${ }^{20}$ Lze uvést např. publikace: HORVATH, Steve. Weighted Network Analysis: Applications in Genomics and Systems Biology. New York: Springer-Verlag, 2011.

${ }^{21}$ Lze uvést např. publikace: KIPLING, Airlin L. a Michael THOMPSON. Network Analysis Methods Applied to Liquid-phase Acoustic Wace Sensors. Analytical Chemistry, 1990, roč. 62, č. 14, s. 1514-1519 nebo CARLUCCI, Lucia, CIANI, Gianfranco a Davide M. PROSERPIO. Polycatenation, polythreading and polyknotting in coordination network chemistry. Coordination Chemistry Reviews, 2003, sv. 246, č. 1-2, s. 247-289.

${ }^{22}$ Lze uvést např. publikaci: RÜCKER, Gerta. Network meta-analysis, electrical networks and graph theory. Research Synthesis Methods, 2012, roč. 3, č. 4, s. 312-324. 
děni např́íklad Moreno, Cartwright, Newcomb a Bavelas v sociologii a sociální psychologii a Barnes s Mitchellem v antropologii. ${ }^{23}$ Počátek sítové analýzy ve společenských vědách je spojen s interdisciplinárními výzkumy propojování matematických modelů se sociologickými a psychologickými výzkumy a to zejména za účelem vyobrazení či grafického znázornění zkoumaných struktur. Sítová analýza jako nová statistická metoda se v tomto ohledu ukázala jako vhodná i z popularizačního hlediska právě díky tomuto vizuálnímu výstupu.

Za pilotní využití sítové analýzy je považován tzv. sociogram Morena z roku 1933, který je současně považován za zakladete sociometrie jako vědního oboru. Sociogram je jednoduchou sítí složenou (1) z bodů (tedy uzlů, jak je vysvětleno následně), které přestavují jednotlivce či sociální skupiny a (2) ze vztahů mezi nimi, které představují linky mezi body (tedy hrany). Tento model se stal velmi brzy populárním právě díky názornému grafickému znázornění, které velmi usnadnilo jeho popularizaci i mezi neodbornou veřejností (a také díky kterému byl poté zveřejněn $\mathrm{v}$ The New York Times). ${ }^{24}$ Grafické modely společenských jevů se po uveřejnění sociogramu staly velmi populárními napříč společenskovědními obory - od sociologie a psychologie ${ }^{25}$ přes ekonomii ${ }^{26}$, politologii ${ }^{27}$ po antropologii ${ }^{28}$ a i právo ${ }^{29}$.

\subsection{TEORETICKÉ PRINCIPY SÍŤOVÉ ANALÝZY}

Ačkoliv je pojem sítové analýzy dnes již běžně spojován se společenskovědními obory, její základy a tedy koncepty, které nám umožňují popsat strukturu sítě a její charakteristiky, vychází z propojení dvou for-

${ }^{23}$ SCOTT, John. Social Network Analysis. 4th Edition. Los Angeles: SAGE Publications, 2017, s. 10.

${ }^{24}$ Tamtéž, s. 12.

${ }^{25}$ Lze uvést např.: OTTE, E.; ROUSSEAU, R. Social network analysis: a powerful strategy, also for the information sciences. Journal of Information Science, 2002, roč. 28, č. 6, s. 441-453; dále EMIRBAYER, M.; GOODWIN, J. Network Analysis, Culture, and the Problem of Agency. American Journal of Sociology, 1994, roč. 99, č. 6, s. 1411-1454; také SCOTT, J. Trend Report Social Network Analysis. Sociology, 1988, roč. 22, č. 1, s. 109-127 a COOK, K. S.; WHITMEYER, J. M. Two Approaches to Social Structure: Exchange Theory and Network Analysis. Annual Review of Sociology, 1992, roč. 18, s. 109-127. 
málních matematických disciplín - statistiky a teorie grafů. V dnešní době je navíc sítová analýza úzce spojena i s počítačovou vědou, která nabízí široké možnosti, jak zpracovávat velké množství dat sítovou analýzou bez nutnosti znát a správně aplikovat matematické a statistické základy této metody. Tímto počítačová věda dělá sítovou analýzu mnohem uživatelsky př́ijemnější a široce aplikovatelnou.

Sítová analýza je založena na dvou základních konceptech (odlišných datových typech): na uzlech (neboli vrcholech) a hranách (neboli spojeních). Uzlem může být kterákoliv výzkumníkem zamýšlená entita (subjekt či objekt) a hranou je pak libovolným způsobem definovaný vztah mezi uzly (entitami). V sítové analýze v právu je jednoduchým příkladem (a častým výzkumným modelem) ten, ve kterém je uzlem právní text - regulatorní text (zákon, zákoník, směrnice nebo jen paragraf či odstavec daného dokumentu) nebo například soudní rozhodnutí (či rozhodnutí jiné autority). Hranou je pak vzájemná citace mezi dvojicí dokumentů - citace předcházející judikatury, citace jiného regulatorního právního textu apod. Sít,

${ }^{26}$ Lze uvést např.: SMITH, D. A.; WHITE, D. R. Structure and Dynamics of the Global Economy: Network Analysis of International Trade 1965-1980. Social Forces, 1992, roč. 70, č. 4, s. 857-893 nebo LINCOLN, J. R.; GERLACH, M. L.; TAKAHASHI, P. Keiretsu Networks in the Japanese Economy: A Dyad analysis of Intercorporate Ties. American Sociological Review, 1992, roč. 57, č. 5, s. 561-585. Dále také DICKEN, P. ; KELLY, P. F.; OLDS, K.; YEUNG, H. W.-C. Chains and networks, territories and scale: towards a relational framework for analysing the global economy. Global Networks, 2001, roč. 1, č. 2, s. 89-112 nebo CALDARELLI, G.; CRISTELLI, M.; GABRIELLI, A.; PIETRONERO, L.; SCALA, A.; TACHELLA, A. A Network Analysis of Countries' Export Flows: Firm Ground for the Building Blocks of the Economy. PLOS ONE, 2012, roč. 7, č. 10, e47278.

${ }^{27}$ Lze uvést např.: LEIFELD, P. Reconceptualizing Major Policy Change in the Advocacy Coalition Framework: A Discourse Network Analysis of German Pension Politics. Policy Studies Journal, 2013, roč. 41, č. 1, s. 169-198 nebo KAHLER, M. (ed.). Networked Politics: Agency, Power, and Governance. Ithaca: Cornell University Press, 2009. Dále také OCELÍK, P. ; SVOBODOVÁ, K.; HENDRYCHOVÁ, M.; LEHOTSKÝ, L.; EVERINGHAM, J.-A.; ALI, S.; BADERA, J.; LECHNER, A. A contested transition toward a coal-free future : Advocacy coalitions and coal policy in the Czech Republic. Energy Research \& Social Science, 2019, sv. 58, Article 101283.

${ }^{28}$ Lze uvést např.: WOLFE, Alvin W. The rise of network thinking in anthropology. Social Networks, 1978-1979, roč. 1, č. 1, s. 53-64 a WOLFE, Alvin W. Anthropologist view of social network analysis and data mining. Social Network Analysis and Mining, 2011, roč. 1, č. 1, s. 3-19.

${ }^{29}$ Bude detailně rozebráno v následující kapitole. 
tvořená z těchto uzlů a hran, je pak strukturou daného datasetu uzlů (dokumentů) dle jejich vzájemných hran (vztah definovaný na základě toho, zda se navzájem citují či nikoliv).

Základním pozorovaným prvkem sítové analýzy je poté graf. V teorii grafů se vyjadřuje uspořádanou dvojicí $G(V, E)$, kde $\mathrm{V}$ je množinou uzlů (z anglického „vertices“) a $E$ je množinou hran (z anglického „edges“), tedy množinou dvojic uzlů, mezi nimiž existuje definovaný vztah. Dle typu hran poté rozlišujeme graf na orientovaný a neorientovaný dle toho, zda rozlišujeme i směr hrany. V případě, že směr nerozlišujeme (znamená to tedy, že pořadí uzlů na obou koncích hrany, kterými je hrana definována, lze volně zaměňovat) jedná se o neorientovaný graf, orientovaný graf je pak ten, kde záleží na pořadí koncových uzlů hrany - tedy odkud a kam hrana vede. Další důležitou vlastností hrany, dle které rozlišujeme typy grafů, je její váha. Jedná se o distinkci dvou typů grafi̊, kde prvním a jednodušším typem je ten, kde mají všechny hrany stejnou váhu a druhým je ten, ve kterém mohou hrany nabývat různé váhy dle definovaného pravidla. Váha hrany bývá obvykle kvantifikována jako další charakteristická proměnná. Vrátíme-li se k uvedenému příkladu o vzájemných citacích právních dokumentů tak $\mathrm{v}$ případě, kdy budeme rozlišovat, odkud a kam vede citace (což zpravidla budeme, jelikož se jedná o esenciální prvek, chceme-li získat představu o struktuře analyzovaných dokumentů), bude se jednat o orientovaný graf. $\mathrm{V}$ případě, když budeme ještě rozlišovat i počet citací (kolikrát daný dokument cituje druhý dokument), bude se jednat o váhu hran a tedy orientovaný ohodnocený graf.

Další důležitou proměnnou, kterou lze popsat daný graf je stupeň vrcholu. Jedná se o počet hran, které jsou spojeny s daným vrcholem. Stupeň vrcholu můžeme dále $\mathrm{u}$ orientovaného grafu dělit na vstupní a výstupní. Vstupní stupeň (indegree) vrcholu je počet hran, které jsou orientovány směrem k tomuto vrcholu, a výstupní stupeň (outdegree) je počet hran, které jsou orientovány směrem od tohoto vrcholu.

Na grafu lze dále změřit a definovat důležité uzly (tedy tzv. centralitu grafu). Centralita grafu je proměnná, která odpovídá na otázku, který uzel je v grafu důležitý. Už ze znění této otázky je patrné, že tuto proměnnou lze 
určit různými způsoby dle toho, jak si autor výzkumu definuje „důležitost“. Přesto však existuje obecně užívaná stupňová centralita, která definuje důležité uzly na základě velikosti jejich stupňů (a to obecných či vstupních nebo výstupních).

Poslední proměnnou, která zde bude zmíněna, je shlukový koeficient. Tento popisuje, jakým způsobem je graf rozdělen do tzv. shluků, tedy podmnožin uzlů, které jsou si navzájem bliže, než jsou si blízké se zbytkem uzlů v grafu. Tento koeficient se obvykle určuje na základě váhy stupňů $\mathrm{v}$ ohodnoceném grafu.

Je patrné, že tento teoretický vhled do fungování sítí nemá za cíl představit všechny možné proměnné a úplný přehled jejich užití a př́ípadně i výpočtů, ale pouze čtenáři nabídnout fundamentální teoretické porozumění sítové analýze tak, aby to pro něj bylo účelné k pochopení tohoto článku. $\mathrm{V}$ př́padě hlubšího zájmu o tuto disciplínu pak uvádím v poznámce pod čarou několik dalších publikací, na které se může čtenář s jistotou matematicky přesných a formalizovaných odpovědí obrátit. ${ }^{30}$

\section{SÍŤOVÉ METODY V PRÁVU}

Základním stavebním kamenem sítové analýzy je vztah mezi entitami spolu s charakteristickými vlastnostmi tohoto vztahu popisovanými př́slušnými sítovými proměnnými. Tento vztah je základním prvkem, který tato metoda zkoumá. Vzhledem $\mathrm{k}$ tomu, že u právních pramenů zkoumáme obvykle primárně jejich obsah, protože právě ten tvoří platné právo, a teprve sekundárně vztah mezi právními prameny (a to navíc většinou pouze $\mathrm{z}$ hlediska hierarchie těchto pramenů, tedy vertikálně), soustředímeli se primárně na vztah před obsahem, jedná se o významný obrat pozornosti. Proto je tento přístup výrazně odlišný od standardního zkoumání právních pramenů. Jedním z cílů této práce je mimo jiné ukázat, že se jedná o obrat možný (existují vztahy, které můžeme empiricky zkoumat) a současně i chtěný (empirické zkoumání vztahů přináší nové hodnotné

\footnotetext{
${ }^{30}$ Teoretický přehled v této kapitole vychází zejména z publikace: BRANDES, Ulrik. Network Analysis: Methodological Foundations. Springer Science \& Business Media, 2005, kterou současně doporučuji k nastudování v případě zájmu o hlubší vhled do tematiky.
} 
informace) a to zejména $\mathrm{z}$ hlediska zpracovávání a vyhledávání právních informací. $^{31}$

V této kapitole bude uveden přehled využití metod sítové analýzy v právu. V základním rozdělení dle Whalena ${ }^{32}$ lze charakterizovat dvě hlavní kategorie využití sítové analýzy v právu: na sociální sítovou analýzu v právu a informační sítovou analýzu v právu. Sociální sítová analýza v právu se metodologicky podobá spíše obecné sociální sítové analýze tak, jak je velmi obecně představena $v$ předchozí kapitole, to znamená zaměřuje se na zkoumání sociálních vztahů mezi aktéry, kterými mohou být nejčastěji osoby či skupiny osob. Pomocí sítové analýzy jsou pak zkoumány tyto vztahy a různé charakteristiky těchto vztahů jako jejich časový vývoj, skupinová dynamika, hierarchie apod. Tento směr, ačkoliv do sítové analýzy zcela jistě patří, však nepřináší informace z hlediska vyhledávání právních informací a jejich zpracovávání a z hlediska poznání obsahu právních pramenů. Pro kompletnost přehledu však také krátce uveden bude, těžiště se však bude nacházet $\mathrm{v}$ přehledu metod aplikace sítové analýzy v právu na právní prameny a tedy informační sítové analýze. Cílem této práce je poté objasnit, že právě tato oblast sítové analýzy v právu je využitelná pro vyhledávání a zpracovávání právních informací.

\subsection{SOCIÁLNÍ SÍŤOVÁ ANALÝZA V PRÁVU}

Aplikace sociální sítové analýzy v právu je metodologicky spíše na hranici se standardním sociologickým výzkumem s využitím sítové analýzy, jelikož předmětem zkoumání jsou právní sociální sítě. V sociální sítové analýze je základním prvkem, který je analyzován, společenský vztah mezi aktéry v síti.

\footnotetext{
${ }^{31}$ Vztahy mezi právními prameny a jejich charakteristiky, které jsou sítovými metodami analyzovány, jsou detailněji rozebrány dále $\mathrm{v}$ textu. Nejjednodušším příkladem jsou určitě citace či reference mezi jednotlivými prameny, tato práce ale obsahuje i další možné vztahy vzniklé na základě sémantické podobnosti dokumentů, př́slušnosti k podobnému tematickému shluku apod.

32 WHALEN, Ryan. Legal Networks: The Promises and Challenges of Legal Network Analysis. Michigan State Law Review. 2016, roč. 2016, s. 552.
} 
Sociální sítová analýza byla v právu aplikována zejména na aktéry podílející se různými způsoby at už na legislativní tvorbě práva, na jeho aplikaci či na jeho zkoumání. Vzhledem $\mathrm{k}$ tomu, že předmětem zkoumání $\mathrm{v}$ těchto studiích nejsou právní informace ani prameny ale samotní aktérii, tedy nejčastěji fyzické či právnické osoby, sítová analýza se zde nejčastěji zabývá otázkami vzájemné interakce a provázanosti aktérů, vytváření zájmových shluků nebo elitních skupin apod. Jednou z prvních studií byla analýza sociálních struktur právníků v Chicagu od autorské dvojice Heinze a Laumanna ${ }^{33}$, na kterou navázali sítovou studií způsobů, jakými právníci ve Washingtonu soukromými zájmy ovlivňují národní (nejen) legislativní tvorbu. ${ }^{34}$ Mezi další př́kladné aplikace patří dále zkoumání vztahů at už uvnitř právních firem či mezi nimi vzájemně, zaměřením těchto typů výzkumů pak bývají často společenské vztahy vznikající při vzájemné konkurenci a kompetitivnosti a nebo opačně vzájemnou spolupracíi ${ }^{35}$, zajímavý je dále mezioborový právně-ekonomický výzkum týkající se sledování sociálních sítí právních firem a jejich vlivu na vývoj cen poskytovaných služeb. ${ }^{36}$ Katz a Stafford se dále zabývali i sociální sítí soudců a jejich vztahů, kde pracovali s hypotézou, že profesní a společenské vztahy ovlivňují soudce při jejich rozhodování. ${ }^{37}$

Důležitou odnoží sociální sítové analýzy je dále aplikace sítových metod v kriminologii za účelem zkoumání sociálních vztahů pachatelů trestné činnosti, jejich skupin či celých kriminálních gangů a teroristických skupin.

33 HEINZ, John P. a Edward O. LAUMANN. Chicago Lawyers: The Social Structure of the Bar [online]. Russell Sage Foundation, 1982 [cit. 06.10.2021].

34 HEINZ, John P., Edward O. LAUMANN a Robert L. NELSON. The Hollow Core: Private Interests in National Policy Making. Harvard University Press, 1993.

35 LAZEGA, Emmanuel a Marijtje VAN DUIJN. Position in formal structure, personal characteristics and choices of advisors in a law firm: A logistic regression model for dyadic network data. Social Networks. 1997, roč. 19, č. 4, s. 375-397. LAZEGA, Emmanuel. The Collegial Phenomenon: The Social Mechanisms of Cooperation Among Peers in a Corporate Law Partnership. Oxford: Oxford University Press, 2001.

${ }^{36}$ UZZI, Brian a Ryon LANCASTER. Embeddedness and Price Formation in the Corporate Law Market. American Sociological Review. SAGE Publications Inc, 2004, roč. 69, č. 3, s. 319344.

${ }^{37}$ KATZ, Daniel M. a Derek K. STAFFORD, 2010. Hustle and Flow: A Social Network Analysis of the American Federal Judiciary. Ohio State Law Journal. (3), s. 457-510. 
V tomto směru se sítová analýza v právu často prolíná se zmiňovanou kriminologií, zkoumá však taktéž ekonomické a sociologické vlivy vzniku trestné činnosti a obecně ekonomicko-sociologické pozadí pachatelů trestné činnosti skrz sítové proměnné. ${ }^{38}$

Přehled studií v této podkapitole tímto rozhodně není vyčerpán, jedná se spíše o nastínění možných směrů a způsobů využití. I tak je patrné, že sítové metody nachází v právu uplatnění i mimo zkoumání obsahu právních pramenů. Protože ale zaměření této práce leží ve využití sítové analýzy pro poznání obsahu práva a zejména konkrétně pro vyhledávání právních informací, autorka se zaměří spíše na druhou kategorii aplikace sítové analýzy v právu - informační sítovou analýzu - v následující podkapitole.

\subsection{INFORMAČNÍ SÍŤOVÁ ANALÝZA V PRÁVU}

Pod pojmem informační sítová analýzy v právu chápeme metody sítové analýzy aplikované na právní prameny, nebo šířeji právní informace a data obecně. Nejčastěji používanými dokumenty jsou pak legislativní či judikatorní právní dokumenty. Jak bude také ukázáno, že vyhledávání a zpracovávání právních informací je pouze jeden $\mathrm{z}$ cílů aplikace metod sítové analýzy, tyto metody jsou na právní prameny aplikovány také za účelem empirického zkoumání některých teoretických právních termínů, dále empirického zkoumání fungování některých právních institutů či celých systémů obecně nebo zjištování vývojových trendů daných institutů apod. Vyhledávání právních informací je tedy pouze jedním z mnoha účelů aplikace sítových metod; jedná se současně o účel svázaný s praktickou

38 Např. LEIGHTON, Barry. The Community Concept in Criminology: Toward a Social Network Approach. Journal of Research in Crime and Delinquency [online]. 25(4), s. 351-374, 1988. ATHEY, Nicholas C. a Martin BOUCHARD. The BALCO scandal: the social structure of a steroid distribution network. Global Crime. 14(2-3), 2013, s. 216-237. NASH, Rebecca, Martin BOUCHARD a Aili MALM. Investing in people: The role of social networks in the diffusion of a large-scale fraud. Social Networks [online]. 35(4), 2013, s. 686-698. BOUCHARD, Martin et al. Criminal Careers in Cyberspace: Examining Website Failure within Child Exploitation Networks. Justice Quarterly: Vol 33, No 7 [online]. FARLEY, Jonathan David. Breaking Al Qaeda Cells: A Mathematical Analysis of Counterterrorism Operations (A Guide for Risk Assessment and Decision Making). Studies in Conflict \& Terrorism: Vol 26, No 6 [online]. MORSELLI, Carlo, Cynthia GIGUÈRE a Katia PETIT. The efficiency/security trade-off in criminal networks. Social Networks [online]. 29(1), 2007, s. 143-153. 
aplikací metod a s koncovým „uživatelem“, který informace vyhledává a který obvykle i vyhodnocuje jejich relevanci. ${ }^{39}$

Informační sítovou analýzu, podobně jako sociální sítovou analýzu, rozlišujeme přirozeně dle typu a povahy zkoumaných dat (ve smyslu uzlů v síti neboli datových bodů) a dle typu a povahy jejích vzájemných vztahů (ve smyslu hran v síti). V právu se nejčastěji setkáváme se sítovou analýzou aplikovanou na normativní právní akty na všech úrovních a na judikaturu, důležité a obsažné odvětví je dále zpracovávání a analýza patentových přihlášek sítovou analýzou. Z hlediska metody tvorby a vzniku hran v síti, tedy z hlediska vzájemných vztahů mezi datovými body, které jsou pro sítovou analýzu typické, se v právu nejčastěji setkáváme s analýzou citační, tedy analýzou vzájemných referencí $\mathrm{v}$ datech, na která sítovou analýzu aplikujeme. $\mathrm{V}$ současnosti lze říci i dle přehledu $\mathrm{v}$ této kapitole, že tento směr v aplikaci sítových metod na právní prameny výrazně dominuje. Až poslední dobou a to zejména $\mathrm{v}$ souvislosti $\mathrm{s}$ rozvojem efektivnějších a přesnějších metod zpracování přirozeného jazyka je na vzájemné vztahy mezi právními prameny nahlíženo i z jiných hledisek než je pouze citační hledisko. Vztahy mezi právními prameny neboli hrany v síti jsou pak tvořeny např. vzájemnou sémantickou podobností jednotlivých pramenů (dokumentů), př́islušností k podobnému tematickému shluku či podobným tematickým zařazením, vzájemnou syntaktickou podobností jednotlivých dokumentů apod. Jedním z dílčích cílů této práce je zmapovat nejen dominantní postavení citační sítové analýzy, která navíc bývá často terminologicky zaměňována s obecným termínem sítová analýza $\mathrm{v}$ právu, ale také představit jiné aplikace sítových metod v právu a vyzdvihnout jejich obecné výhody pro práci s právními prameny, pro jejich poznání a vyhledávání či získávání.

Za tímto účelem je tato kapitola rozdělena na dvě části: na přehledovou část zabývající se citační analýzou a citační sítovou analýzou a na přehledovou část zabývající se ostatními aplikacemi účelně nazvanou textovou sítovou analýzou v právu. Textová sítová analýza $\mathrm{v}$ tomto článku znamená

39 Otázkou relevance vyhledaných informací a jejího hodnocení se budeme zabývat konkrétněji v následující kapitole 3. 
metodu, která sítovými metodami zkoumá textový obsah právních pramenů jako závazný obsah práva za použití metod přirozeného zpracování jazyka založených na strojovém učení a umělé inteligenci.

\subsection{CITAČNÍ ANALÝZA A CITAČNÍ SÍŤOVÁ ANALÝZA ${ }^{40}$}

Citační sítová analýza je metoda aplikovaná nejen v právu, její základy můžeme hledat v bibliografickém výzkumu. Citace mezi (právními či jinými) dokumenty totiž přirozeně tvoří sít, která přímo vybízí $\mathrm{k}$ analýze sítovými metodami, př́́padně metodami teorie grafů, $\mathrm{z}$ jejich strukturálního a komplexního hlediska vzájemných vztahů. V takové síti jednotlivé dokumenty tvoři uzly a vzájemné citace hrany mezi nimi, tyto hrany pak mohou v závislosti na typu analýza a účelu zkoumání nabývat směru či váhy apod. Dle zvolené metodologie pak lze pozorovat i vývoj sítě a vznik uzlů i hran v závislosti na dalších externích proměnných, např. typicky na času. Získané metriky a jejich hodnoty potom pomáhají odpovídat na některé ryze právně teoretické otázky, jako např. jakým způsobem vzniká v precedentním systému doktrína stare decisis, jak bude ukázáno dále. ${ }^{41} \mathrm{~V}$ následujícím přehledu citační analýzy se budou prolínat jak právní tak neprávní studie zabývající se citacemi; můžeme pozorovat vývoj od vzniku myšlenky citačního indexu a zdůraznění jeho možné role při analýze velkého množství vzájemně souvisejících dokumentů až po komplexní sítě mapující celé datasety dokumentů s poměrně sofistikovanými proměnnými kvantitativně popisujícími jejich vlastnosti ve vzájemných souvislostech.

Jedním z prvních citačních experimentů v právu byl Shepherd analyzující citační praxi Nejvyššího soudu USA v jeho judikatuře za účelem vývoje citačního indexu už v roce $1873 .{ }^{42} \mathrm{Na}$ tuto myšlenku bylo navázáno až v polovině 20. století a to zejména prací Garfielda zabývající se biblio-

40 Dílčí část této podkapitoly týkající se zejména citační sítové analýzy soudních rozhodnutí byla publikována v podkapitole č. 6.3.4 v části I. monografie: HARAŠTA, Jakub, Terezie SMEJKALOVÁ, Tereza NOVOTNÁ, Jaromír ŠAVELKA, Radim POLČÁK, František KASL, Pavel LOUTOCKÝ a Jakub MÍŠEK. Citační analýza judikatury. 1. vydání. Praha: Wolters Kluwer, 2021. $256 \mathrm{~s}$. V této publikaci je tato kapitola rozšǐřena o širší souvislosti a nové zdroje.

${ }^{41}$ FOWLER, James H. a Sangick JEON. The authority of Supreme Court precedent. Social Networks [online]. 30(1), 16-30, 2008. ISSN 03788733. 
grafickými citacemi a jejich analýzou, jeho práce bývá považována za základ citační analýzy a Garfield za zakladatele bibliografie. ${ }^{43}$ Paralelně s vývojem citační indexace v bibliografii vznikaly ve 40. letech 20 . století první citační studie patentových přihlášek, reagující na povinnost uvedení seznamu existujících zapsaných patentů relevantních pro předmět patentové přihlášky přímo do této přihlášky. Takové množství vzájemných citací zapsaných patentů pak umožnilo provádět citační analýzu ve velkém měřítku a tímto nejen usnadnit práci patentovým zástupcům ${ }^{44}$, ale i sledovat vývojové trendy patentů a technologického vývoje obecně. ${ }^{45}$

$\mathrm{V}$ reakci na rozvoj citační indexace pak v roce 1971 Zunde definoval tři hlavní směry aplikace výpočtu citačních indexů dokumentů a jejich účel: pro hodnocení vědy a výzkumu (podobně jak dnes známe výpočty citačních indexů odborných časopisů apod.), dále pro nastínění historického vývoje vědy, technologií nebo právě konkrétních (např. právních) institutů a dále právě pro vyhledávání a získávání informací a to zejména v právu. ${ }^{46}$ Chronologicky následovala citační studie judikatury Nejvyššího soudu USA Stephena M. Marxe, která vybízela k publikování seznamů citovaných soudních rozhodnutí za účelem vyhledávání a získávání relevantních soudních rozhodnutí při rešerši judikatury. ${ }^{47} \mathrm{Na}$ tuto myšlenku navázal Tapper studií, která velmi progresivně kombinovala citační analýzu a ur-

${ }^{42}$ NEALE, Thom. Citation Analysis of Canadian Case Law. Journal of Open Access to Law. 2013, roč. 1, s. 2.

${ }^{43}$ GEIST, Anton. Using Citation Analysis Techniques For Computer-Assisted Legal Research in Continental Jurisdictions, Graduate thesis, University of Edinburgh, 2009, s. 66.

${ }^{44}$ GARFIELD, Eugene. Citation Indexing: Its Theory and Application in Science, Technology, and Humanities. B.m.: Isi Press, 1979, s. 37 - 40. ISBN 978-0-89495-024-7.

45 DAHLIN, Kristina, Margaret TAYLOR a Mark FICHMAN. Today's Edisons or weekend hobbyists: technical merit and success of inventions by independent inventors. Research Policy [online]. 33(8), 2004, s. 1167-1183. FLEMING, Lee a Olav SORENSON. Technology as a complex adaptive system: evidence from patent data. Research Policy [online]. 30(7), 2001, s. 1019-1039. ALBERT, M. B., D. AVERY, F. NARIN a P. MCALLISTER. Direct validation of citation counts as indicators of industrially important patents. Research Policy [online]. 20(3), 1991, s. 251-259.

${ }^{46}$ GEIST, Anton. Using Citation Analysis Techniques For Computer-Assisted Legal Research in Continental Jurisdictions, Graduate thesis, University of Edinburgh, 2009, s. 66.

47 MARX, Stephen M. Citation Networks in the Law. Jurimetrics Journal. Vol. 10, 1979, s. 121137. 
čení podobnosti soudních rozhodnutí porovnáním vektorů zachycujících citovaná rozhodnutí, pro tento účel místo standardní cosinové podobnosti dvou vektorů vyvinul vlastní výpočet podobnosti. ${ }^{48}$ Spolu s rozvojem citačních studií v právu pak byly více diskutovány i její limity, na což reagoval Tutle studií, ve které navrhnul model vyhledávání informací za pomocí právě citačních indexů beroucích $\mathrm{v}$ úvahu i kontext citace $\mathrm{v}$ rámci právního dokumentu. ${ }^{49}$

Opravdový rozvoj citační analýzy ale umožnilo až spíše 21. století paralelně s rozvojem informačních technologií a automatického zpracování velkého množství textu, který umožnil vznik algoritmů a softwarů pro jednoduší získání a zpracování citačních datasetů. Tyto okolnosti také zapříčinily propojení citační analýzy s metodou sítové analýzy a tím podpořily argument jejího obecného využití pro empirickou analýzu právních pramenů a dokonce zodpovězení některých fundamentálně teoretických právních otázek.

Nejčastěji bývají v tomto směru zpracovávány datasety soudních rozhodnutí Nejvyššího soudu USA a následně podobně i rozhodnutí Soudního dvora EU. Zajímavý je v tomto směru i odklon od předchozího účelu citačních studií v právu, kterým bylo zejména vyhledávání právních informací, jejich strukturalizace a lepší získávání (jako např. výše zmínění citační analýza rozhodnutí Nejvyššího soudu USA či citační analýza patentových přihlášek). Ve 21. století, jak bude ukázáno následně, se cíl citačních a sítových studií postupně přesunul spíše $\mathrm{k}$ empirickému podložení velmi teoretických právních hypotéz a výzkumných otázek týkajících se samotného fungování soudních systémů a to zejména funkci a důležitost precedentů či definice vágního termínu „relevance“ soudních rozhodnutí apod.

Zkoumání vzájemných citací judikatury Nejvyššího soudu USA provedl Thomas A. Smith, který ve své práci potvrdil tzv. power law trend u ci-

48 Tapper, Colin. The Use of Citation Vectors for Legal Information Retrieval. Journal of Law \& Information Science, Vol. 1, No. 2, 1981, s. 131- 161.

49 GEIST, Anton. Using Citation Analysis Techniques For Computer-Assisted Legal Research in Continental Jurisdictions, Graduate thesis, University of Edinburgh, 2009, s. 58. 
tovaných rozhodnutí. ${ }^{50}$ Nejproslulejší citační sítové studie jsou dále dvě návazné studie z let 2007 a 2008 od autorského kolektivu vedeného Fowlerem. ${ }^{51}$ Tento autorský kolektiv provedl extenzivní výzkum citačního chování Nejvyššího soudu USA, na jehož rozhodnutí z let 1752 až 2002 aplikoval sítové metriky. ${ }^{52}$ Cílem bylo empiricky zkoumat otázku „důležitosti“ konkrétního rozhodnutí v síti a vztahu této charakteristiky $\mathrm{k}$ indegree a outdegree proměnným. ${ }^{53}$ Hypotézy Fowlera a kol. založené na sítové centralitě uzlu se potvrdily a dokonce dokázaly s určitou chybovostí předvídat, které rozhodnutí bude $\mathrm{v}$ síti nabývat důležitosti $\mathrm{v}$ čase. ${ }^{54}$ Rozhodnutí Nejvyššího soudu USA dále zkoumal také autorský kolektiv vedený Crossem s odlišným záměrem zjistit spíše za jakým účelem soudci citují konkrétní rozhodnutí a zda tak činí rozdílně či zda vykazuje jejich citační praxe podobné vlastnosti. ${ }^{55}$ Whalen poté navázal ve svém výzkumu na výsledky Fowlera a kol. a výzkum rozšíríl o časové hledisko. Tento př́stup mu umožnil sledovat sít a její vývoj v čase a to zejména s ohledem na důležitá rozhodnutí v síti. ${ }^{56}$

Winkels a kol. replikoval tento výzkum jako první mezi kontinentálními právními systémy a to na dataset rozhodnutí Nejvyššího soudu v Nizozemí. ${ }^{57}$ Ačkoliv tento autorský kolektiv došel k podobným výsledkům, jako autorský kolektiv vedený Fowlerem, při aplikaci sítových metod na nepre-

${ }^{50}$ SMITH, Thomas A. The Web of Law. San Diego Legal Studies Research. Paper No. 06-11, 2005.

${ }^{51}$ FOWLER, James H., Timothy R. JOHNSON, James F. SPRIGGS, Sangick JEON a Paul J. WAHLBECK. Network Analysis and the Law: Measuring the Legal Importance of Precedents at the U.S. Supreme Court. Political Analysis [online]. 15(3), s. 324-346, 2007.

52 FOWLER, James H. a Sangick JEON. The authority of Supreme Court precedent. Social Networks [online]. 30(1), s. 16-30, 2008.

53 Indegree znamená vstupní stupeň uzlu, outdegree je výstupním stupněm uzlu, oba termíny blíže popsány výše na s. 49.

54 Tamtéž, s. 13 a násl.

55 CROSS, Frank B. a kol. Citations in the U.S. Supreme Court: an Empirical Study of Their Use and Significance. University Illinois Law Review. No. 2, 2010, s. 491.

56 WHALEN, Ryan. Modeling Annual Supreme Court Influence: The Role of Citation Practices and Judicial Tenure in Determining Precedent Network Growth. In: Ronaldo MENEZES, Alexandre EVSUKOFF a Marta C. GONZÁLEZ, ed. Complex Networks [online]. Berlin, Heidelberg: Springer Berlin Heidelberg, Studies in Computational Intelligence, s. 169-176, 2013. 
cedentní soudní systémy nejsou závěry tak jednoznačné. Winkels a kol. i přesto došel ke stejnému závěru ohledně definování důležitých rozhodnutí v síti pomocí sítových metrik jako Fowler a kol. ${ }^{58}$ Komparační studii několika sítových algoritmů pak provedl Malmgren na datasetu rozhodnutí Soudního dvora EU. ${ }^{59}$ Odlišnou aplikaci metod použili Clark a Lauderdale, kteří pomocí sítové analýzy ověřovali vývoj argumentačních linek napříč citujícími se rozhodnutími. ${ }^{60}$ Neale poté využil metod citační sítové analýzy na dataset rozhodnutí $\mathrm{k}$ zodpovězení dvou otázek týkajících se předpovězení důležitosti konkrétního rozhodnutí spolu s časem, od kdy začne rozhodnutí nabývat důležitosti. ${ }^{61}$ Snaha o definici „důležitých“ soudních rozhodnutí v síti je předmětem jedné z nejnovějších studií od autorského kolektivu Wagha a kol. ${ }^{62}$ Tato práce je ale komparačního charakteru a porovnává citační sítovou analýzu s analýzou semantickou, která se skládá z výpočtů cosinové podobnosti textů příslušných rozhodnutí a citační analýza zde vychází jako metoda se signifikantně přesnějšími výsledky. Jednou z mála prací, které byly dokonce završeny vznikem nástroje pro lepší orientaci v soudní rozhodovací praxi je ta od Kuppevelta a Dijcka. ${ }^{63}$ Autoři v této práci analyzovali citace soudních rozhodnutí Nejvyššího soudu v Nizozemsku a ze vzniklé sítě vytvořili veřejně dostupnou webovou aplika-

57 WINKELS, Radboud, Jelle RUYTER a Henryk KROESE. Determining Authority of Dutch Case Law [online]. SSRN Scholarly Paper ID 2013190. Rochester, NY: Social Science Research Network, 2011 [vid. 2019-10-06]. Dostupné z: https://papers.ssrn.com/abstract $=2013190$.

58 Tamtéž.

59 MALMGREN, Staffan. Towards a theory of jurisprudential relevance ranking. Using Link Analysis on EU Case Law. Graduate thesis, Stockholm University, 2011, 115 s.

60 CLARK, Tom S. a Benjamin E. LAUDERDALE. The Genealogy of Law. Political Analysis. Cambridge University Press, 2012, roč. 20, č. 3, s. 330-331.

61 NEALE, Thom. Citation Analysis of Canadian Case Law. Journal of Open Access to Law. 2013, roč. 1, s. 1-60.

62 WAGH, R. a D. ANAND, 2017. Application of citation network analysis for improved similarity index estimation of legal case documents : A study. In: 2017 IEEE International Conference on Current Trends in Advanced Computing (ICCTAC): 2017 IEEE International Conference on Current Trends in Advanced Computing (ICCTAC) [online]. s. 1-5.

63 KUPPEVELT, Dafne VAN a Gijs VAN DIJCK, 2017. Answering Legal Research Questions About Dutch Case Law with Network Analysis and Visualization. In: Legal Knowledge and Information Systems: JURIX 2017: The Thirtieth Annual Conference. B.m.: IOS Press, s. 95. 
ci umožňující vyhledávat soudní rozhodnutí dle různých měřítek. ${ }^{64} \mathrm{~V}$ přiloženém článku pak obhajují výsledky vyhledávání v aplikaci komparací s vyhledávací činností právníka. Panagis a kol. navázali ve svojí studii na předchozí zmíněné výsledky a obohatili citační analýzu soudních rozhodnutí Soudního dvora Evropské unie o implicitní citace, tedy ty, které nejsou označené identifikátorem rozhodnutí, ale spíše implicitně zahrnuté v textu. ${ }^{65}$ Kvůli extrakci těchto citací tedy provedli sémantickou analýzu a zahrnuli nejen explicitní identifikátory, ale i implicitní reference. Práce má poté dvě části - v první tvoří sít z citací konkrétních částí soudních rozhodnutí a v druhé jsou poté zahrnuty i citace celých rozhodnutí. Tímto tato práce obsahuje i část, ve které autoři poměrně úspěšně predikují konkrétní části soudního rozhodnutí, které jsou citovány, i z referencí odkazujících „pouze“ na celé soudní rozhodnutí. Důležitými a vyčerpávajícími studiemi sítové analýzy citací jsou pak na závěr ty z pera Derléna a Lindholma. ${ }^{66}$ Jejich hlavní otázkou je role Soudního dvora Evropské unie a jeho rozhodovací praxe na celý právní systém Evropské unie a zjištují značné podobnosti s citační sítí Nejvyššího soudu USA dle Fowlera. ${ }^{67}$

Bylo jen otázkou času, kdy se podobná metodologie jako ta, kterou uvedl Fowler a Winkels, aplikuje vedle soudních rozhodnutí i na regulatorní právní texty. Ačkoliv se tento směr odlišuje od citační analýzy s tím, že ta se týká pouze citací v soudních textech, princip je stejný - sledovat vzájemné citace mezi právními dokumenty a pozorovat chování této sítě a kvantifikaci jejích vlastností za účelem zjištění toho, jak funguje. První studií je $\mathrm{v}$ tomto směru ta od Bommarita a Katze provedená na zákoníku USA. Ti

${ }^{64}$ Case Law App. Dostupné z: https://www.research-software.nl/software/case-law-app.

65 PANAGIS, Yannis, Urska SADL a Fabien TARISSAN, 2017. Giving every case its (legal) due The contribution of citation networks and text similarity techniques to legal studies of European Union law. In: 30th International Conference on Legal Knowledge and Information Systems (JURIX'17). B.m.: IOS Press, s. 59-68.

${ }^{66}$ DERLÉN, Mattias a Johan LINDHOLM, 2015. Characteristics of Precedent: The Case Law of the European Court of Justice in Three Dimensions [online]. SSRN Scholarly Paper ID 2677555. Rochester, NY: Social Science Research Network. DERLÉN, Mattias a Johan LINDHOLM, 2017. Is it Good Law? Network Analysis and the CJEU's Internal Market Jurisprudence. Journal of International Economic Law [online]. 20(2), 257-277..

${ }^{67}$ FOWLER, James H. a Sangick JEON. The authority of Supreme Court precedent. Social Networks [online]. 30(1), s. 16-30, 2008. 
navíc tuto práci rozšířili o časový vývoj a sledovali, jakým způsobem roste sít v čase. ${ }^{68}$ Tato práce byla zreplikována autorským kolektivem Bouleta a kol. aplikující sítovou analýzu na většinu francouzských zákoníků a citace mezi nimi. ${ }^{69}$ Stejný autorský kolektiv provedl později nástavbovou studii, která pracuje už i s váhou jednotlivých hran podle množství citací mezi jednotlivými uzly. ${ }^{70}$ Pomocí této metody podobně definovali důležité zákoníky a potvrdili tzv. power law - tedy, že existuje malé množství zákoníků, které však obsahují většinu in- i outdegree citací. Jedna z pozdějších studií v aplikaci metod sítové analýzy na texty regulatorního charakteru je poté ta od Koniarise a kol., ve které se snaží vytvořit kompletní model právních zdrojů Evropské unie na základě jejich vzájemných citací. ${ }^{71}$ Tuto studii dále obohacuje také o časový vývoj. Potvrzuje fungování power law i na těchto právních dokumentech a navíc zjištuje, že roste hustota sítě, jelikož rychleji vzrůstá počet vzájemných citací než počet nových dokumentů. ${ }^{72}$

Ačkoliv nastal určitý odklon od praktické aplikace citační analýzy pro vyhledávání či řazení informací a zdrojů, některé pokusy však byly v tomto směru zaznamenány. Geist použil citační sítové metriky a navrhnul zjednodušení vyhledávání rakouských právních dokumentů v právních informačních systémech. ${ }^{73}$ Opijnen použil podobnou metodu a použil citační data $\mathrm{k}$ automatickému hodnocení soudních rozhodnutí a k oddělení důleži-

68 BOMMARITO, Michael J. a Daniel M. KATZ, 2010. A mathematical approach to the study of the United States Code. Physica A: Statistical Mechanics and its Applications [online]. 389(19), 4195-4200..

69 BOULET, Romain, Pierre MAZZEGA a Daniele BOURCIER, 2011. A network approach to the French system of legal codes-part I: analysis of a dense network. Artificial Intelligence and Law. 19(4), 333-355.

70 BOULET, Romain, Pierre MAZZEGA a Danièle BOURCIER, 2018. Network approach to the French system of legal codes part II: the role of the weights in a network. Artificial Intelligence and Law. 26(1), 23-47.

71 KONIARIS, Marios, Ioannis ANAGNOSTOPOULOS a Yannis VASSILIOU, 2017. Network Analysis in the Legal Domain: A complex model for European Union legal sources. Journal of Complex Networks. 6(2), 243-268.

72 Tamtéž.

73 GEIST, Anton. The Open Revolution: Using Citation Analysis to Improve Legal Text Retrieval. European Journal of Legal Studies. 2008, roč. 2, č. 3, s. 137-145. 
tých od nedůležitých za účelem snadnějšího vyhledávání soudních rozhodnutí uživateli. ${ }^{74}$

Jak bylo ukázáno výše, aplikace sítové analýzy v různých právních odvětvích a různé právní entity či dokumenty má široký potenciál a lze předpokládat rostoucí nárůst jejího využívání. Ačkoliv lze pomocí kvantitativních proměnných odpovědět i na abstraktně teoretické právní otázky, nelze však považovat sítovou analýzu za všespásnou a je nutné uvažovat i o jejích limitech. Whalen ve svém review týkajícím se využití metod sítové analýzy uvádí, že je nutné v dalším vývoji technik sítové analýzy její limity brát $\mathrm{v}$ úvahu a př́padně je překonávat. ${ }^{75}$ Sám v tomto ohledu navrhuje zejména využití přesnějších a detailnějších dat a sofistikovanějších technik. Budoucnost vývoje sítové analýzy v právu leží podle něj zejména v multidimenzionálním uvažování o uzlech a zejména o hranách mezi nimi, tedy spíše $\mathrm{v}$ orientovaných sítích s rozlišením váhy jednotlivých hran. ${ }^{76}$ Dále argumentuje za širší využívání časového vývoje sítě a jejího chování v dlouhodobejššch horizontech. ${ }^{77}$ Dle autorky je také potřebné nezatracovat spolu se sítěmi ve velkých měřítcích kvalitativní analýzu, spíše naopak kombinaci těchto dvou metod považuje za další důležitý krok k empirickému popisu a pochopení právních systémů.

\subsubsection{TEXTOVÁ SÍŤOVÁ ANALÝZA V PRÁVU}

Pod pojmem „textová sítová analýza v právu“ se v rámci této práce rozumí veškeré metody zpracování přirozeného jazyka a tzv. dolování textu (z anglického „text mining"), které jsou na právní prameny či obecněji dokumenty aplikovány v kombinaci se sítovou analýzou. Právní prameny či dokumenty tedy tvoří hlavní datové body a soubory (uzly v síti), které jsou zpracovávány metodami zpracování přirozeného jazyka; sítová analýza je pak aplikována za účelem zkoumat a popsat jejich vzájemné vztahy. Právě tyto

\footnotetext{
74 VAN OPIJNEN, Marc. A model for automated rating of case law. In: Proceedings of the ICAIL '13, Rome, Italy: ACM Press, 2013.

75 WHALEN, Ryan, 2016. Legal Networks: The Promises and Challenges of Legal Network Analysis. Michigan State Law Review. 2016, 539.

76 Tamtéž, s. 554 a násl.

77 Tamtéž, s. 554 a násl.
} 
vztahy a jejich vznik a charakteristika je to, co odlišuje textovou sítovou analýzu od analýzy citační (ačkoliv se tyto metody samozřejmě v mnoha ohledech prolínají) a současně určuje charakteristiku sítě. V textové sítové analýze jsou tyto vztahy konstruovány pomocí metod přirozeného zpracování jazyka, jedná se tedy o kvantitativní vlastnosti jednotlivých textových dokumentů či pramenů vyjadřující jejich vzájemnou podobnost či blízkost. Nejčastěji se bude jednat o vzájemnou podobnost dokumentů, která může být založena na sémantickém či syntaktickém rozboru textu, dále příslušnost $\mathrm{k}$ tematickým celkům nebo shlukům, a nebo např. vztah jednotlivých dokumentů k obecným právním konceptům apod. Pokud jsou tedy jednotlivé právní prameny (např. soudní rozhodnutí) uzly v síti, hranami mezi nimi pak nejsou vzájemné citace, ale např. vzájemná sémantická podobnost textů těchto rozhodnutí vážená metrikou podobnosti (tedy velmi konkrétně - sémanticky podobná rozhodnutí budou v síti propojena „silnějši“ ' hranou než rozhodnutí sémanticky velmi málo podobná). V aplikaci textové sítové analýzy pak tvorba sítě nemusí být vždy úplně přímočará, jelikož sít sama o sobě není primárním výsledkem aplikace metod přirozeného zpracování jazyka a dolování textu, tím je spíše obohacení původních datových souborů novými daty, metadaty či informacemi, nicméně právě proto je dle autorky sítový přístup výhodný - protože umožnuje tato nová data dále obohatit $\mathrm{v}$ dalších kontextuálních úrovních $\mathrm{v}$ rámci sítě.

Vzhledem k uvedenému spíše volnějšímu konceptu vztahu mezi dokumenty se pak aplikace sítové analýzy častěji než při analýze citací metodologicky prolíná s obecnější teorií grafi̊, shlukovou analýzou a dále i vizuální textovou analýzou. Všechny tyto metody jsou však založené na společném konceptu vztahu mezi datovými body a jeho zkoumáním. Hlavním rozdílem ovšem je to, že uzly nebo datové body nejsou často přímo vzájemně propojeny hranami, ale rozhoduje spíše jejich vzájemná blízkost či pozice na dokumentové mapě. Vzhledem k tomu, že relativní pozice uzlu a vztah k ostatním uzlům je klíčový pro tento typ analýzy, v principu jsou tyto metody sítové analýze příbuzné a často pak také používají podobných metrik, které je popisují, proto jsou v této práci také zahrnuty. 
Metody uvedené v následující části jsou zaměřené dvěma hlavními směry, nelze tyto směry však brát odděleně, oba se vzájemně často prolínají. Prvním bude sítová analýza v kombinaci se sémantickou analýzou podobnosti právních pramenů, základním vztahem zde bude vzájemná sémantická podobnost dvou právních pramenů či dokumentů. Druhým směrem bude pak shluková analýza právních pramenů, základním zkoumaným vztahem zde bude vzájemná tematická blízkost právních dokumentů.

Sémantická sítová analýza je zavedenou kvantitativní lingvistickou metodou, nejčastěji sloužící k analýze konceptů a jejich sémantické blízkosti. V rámci vyhledávání a získávání právních informací s ohledem na práci s právními prameny je však nutné obvykle zpracovávat celé právní dokumenty (soudní rozhodnutí, právní předpisy). V sémantické sítové analýze pak tyto dokumenty tvoří uzly v síti a jejich vzájemná podobnost hrany. V takové situaci je pak nutné uvažovat nejprve hodnocení existence vztahu - tzn. zda vztah (hrana) vůbec existuje a poté případně jeho váhu, tedy jak „silný“ vztah je. Sít však bude vždy neorientovaná, protože vzájemná podobnost dvou dokumentů je vždy vzájemná. Kombinace sémantické podobnosti a sítové analýzy bohužel není v právu př́liš častá. Jedním $\mathrm{z}$ pokusů aplikovat sémantickou analýzu v kombinaci s analýzou sítovou na soudní rozhodnutí je studie Wagha a kol., ve které však vyplynula relevance sémanticky podobných soudních rozhodnutí menší než relevance rozhodnutí, které se navzájem citují. Tedy citační analýza byla v komparaci přesnější. $^{78}$

Druhým významným směrem je shluková analýza (často v kombinaci $\mathrm{s}$ dalšími metodami jako např. modelováním témat z právních dokumentů). Vzhledem k tomu, že shluková analýza zejména $\mathrm{v}$ kombinaci s modelováním témat má poměrně dlouho historii užití např́íc vědními obory, i aplikací v právním odvětví můžeme nalézt více než u sémantické sítové analýzy. Některé přístupy dále zahrnují i vizualizaci vztahů mezi právními dokumenty. Shluková analýza typicky zkoumá blízkost jednotlivých doku-

78 WAGH, R. a D. ANAND, 2017. Application of citation network analysis for improved similarity index estimation of legal case documents : A study. In: 2017 IEEE International Conference on Current Trends in Advanced Computing (ICCTAC): 2017 IEEE International Conference on Current Trends in Advanced Computing (ICCTAC) [online]. s. 1-5. 
mentů vůči sobě a tvorbu tzv. shluků dokumentů, které jsou si vzájemně bližší mezi sebou než s ostatními dokumenty v síti.

Mezi aplikace shlukové analýzy v právu patří práce Meikla a Schweighofera zabývající se shlukovou analýzou mezinárodních smluv. ${ }^{79}$ Lu a kol. aplikovali shlukovou analýzu dokonce na dílčí témata segmenti̊ soudních rozhodnutí. ${ }^{80}$ Gorski úspěšně aplikoval shlukovou analýzu na novelizace polského občanského zákoníku, které dokázal takto rozřadit do tematických shluků dle právních institutů. ${ }^{81}$ Do kategorie shlukové analýzy dokumentů v kombinaci s vizualizací a dokumentovými mapami v právu lze zahrnout práci Jungiewicze a Lopucinzskeho, kteří komparují dvě zobrazovací metody (t-SNE a PCA) v aplikaci na soudní rozhodnuti polských soudi̊. Další aplikací shlukové analýzy je ta od autorské dvojice Kumar a Raghuveer $^{82}$, kteří $\mathrm{k}$ výpočtu podobnosti mezi soudními rozhodnutími využili algoritmu modelování témat a dále pak zjištovali podobnost mezi rozhodnutími na základě přiřazených témat. ${ }^{83}$ Toto autorské duo navázalo na tuto svoji práci obohacením shlukové analýzy o sumarizaci textů soudních rozhodnutí. $^{84}$ Tian a kol. využili shlukovou analýzu v kombinaci se sémantickou analýzou k detekci kontroverzních bodi̊ v soudních rozhodnutích. ${ }^{85}$ Autorský tým vedený Nandou využil metod shlukové sémantické analýzy

79 MERKL D. and SCHWEIGHOFER, Erich. En route to data mining in legal text corpora: Clustering, neural computation, and international treaties. In Proceedings of the 8th International Workshop on Database and Expert Systems Applications (DEXA '97), 1997.

80 LU, Qiang, Jack G. CONRAD, Khalid AL-KOFAHI a William KEENAN, 2011. Legal document clustering with built-in topic segmentation. In: the 20th ACM international conference: Proceedings of the 20th ACM international conference on Information and knowledge management - CIKM '11 [online]. Glasgow, Scotland, UK: ACM Press, s. 383.

81 GÓRSKI, Lukasz. Towards Legal Change Analysis: Clustering of Polish Civil Code Amendments [online]. CEUR-WS.org, 2019. CEUR Workshop Proceedings. s. 5.

82 JUNGIEWICZ, Michał a Michał ŁOPUSZYŃSKI, 2015. Towards Meaningful Maps of Polish Case Law. In: Legal Knowledge and Information Systems. IOS Press, s. 185-186. DOI: 10.3233/978-1-61499-609-5-185

83 KUMAR, Ravi V. and RAGHUVEER, K. Legal Documents Clustering using Latent Dirichlet Allocation. International Journal of Applied Information Systems. 2(6):27-33, 2012.

84 VENKATESH, Ravi kumar. Legal Documents Clustering and Summarization using Hierarchical Latent Dirichlet Allocation. IAES International Journal of Artificial Intelligence (IJAI). 2013, roč. 2, č. 1, s. 27-35.

85 TIAN, Xin et al. K-Means Clustering for Controversial Issues Merging in Chinese Legal Texts. Legal Knowledge and Information Systems. IOS Press, 2018, s. 215-219. 
textu ustanovení právního předpisu v rámci vyřešení problému nalezení aplikovatelného ustanovení občanského zákoníku vưči konkrétní právní otázce. $^{86}$ Conrad et al. provedli komparační studii několika shlukových algoritmů a to jak na primární právní prameny tak i na sekundární. ${ }^{87}$ K identifikaci argumentů v soudních rozhodnutích Evropského soudu pro lidská práva využil autorský kolektiv vedený Poudyalem shlukovou analýzu sémantické reprezentace rozhodnutí. ${ }^{88}$

Dle přehledu v této podkapitole je patrné, že ačkoliv využití sémantické sítové a shlukové textové analýzy není tak rozšǐřené jako využití analýzy citační, přesto můžeme $\mathrm{v}$ tomto ohledu sledovat postupný vývoj metod a jejich aplikace a zvyšující se zájem o tyto metody i v analýze právních pramenů. $\mathrm{V}$ textové sítové a shlukové analýze lze pozorovat, podobně jako u citační analýzy, v některých studiích důraz na vyhledávání a získávání právních informací a tedy praktickou stránku možného využití metod. Výhody a limity využití všech uvedených metod budou dále nastíněny v následující kapitole.

\section{JAK MOHOU SÍŤOVÉ METODY POMOCI PŘI ZPRACOVÁVÁNÍ A VYHLEDÁVÁNÍ PRÁVNÍCH INFORMACÍ?}

V předchozích dvou kapitolách byl nastíněn vývoj a spektrum použití metod sítové analýzy a metod jí příbuzných v právu. Cílem přehledu bylo zejména ukázat jejich univerzálnost a také cíl a účel poznávání zkoumaných informací či objektů pomocí těchto metod. V této kapitole bych chtěla navrhnout některé zpo̊soby použití sítové analýzy v právu pro vyhledávání a zpracovávání právních informací.

${ }^{86}$ NANDA, Rohan et al. Legal Information Retrieval Using Topic Clustering and Neural Networks [online]. In: Proceedings of COLIEE 2017. EPiC Series in Computing. 2017.

87 CONRAD, Jack G., Khalid AL-KOFAHI, Ying ZHAO a George KARYPIS, 2005. Effective document clustering for large heterogeneous law firm collections. In: Proceedings of the 10th international conference on Artificial intelligence and law [online]. New York, NY, USA: Association for Computing Machinery, s. 177-187.

88 POUDYAL, Prakash, Teresa GONÇALVES a Paulo QUARESMA. Using Clustering Techniques to Identify Arguments in Legal Documents [online]. In: CEUR Workshop Proceedings. 2019, s. 8 . 
Jak již bylo výše uvedeno, základem sítové analýzy je vztah mezi entitami. Existence či váha tohoto vztahu by tedy měla být klíčová i v případě využití sítové analýzy pro vyhledávání právních informací. $\mathrm{S}$ důrazem na tento vztah by tedy pak měly být navrhovány i zpơsoby využití sítové analýzy pro vyhledávání právních informací.

Citační analýza a to zejména judikatury se přímo nabízí k návrhovému systému rozhodnutí, které se vzájemně citují a to oběma směry. ${ }^{89}$ Jak však již někteří citovaní autoři zaznamenali, rozhodnutí může být citováno $\mathrm{z}$ různých důvodi̊ (často je $\mathrm{v}$ jednom rozhodnutí řešeno více právních otázek) a ne vždy uživatele zajímají všechny důvody a právní otázky $\mathrm{v}$ jednom rozhodnutí obsažené. $\mathrm{V}$ takovém případě se pak nabízí řešení kombinace citační analýzy s některou další metodou přirozeného zpracování jazyka, a to zejména s automatickou segmentací soudních rozhodnutí nebo s metodou rozpoznání právního tématu a klasifikace citací dle témat. Automatická segmentace rozhodnutí by $\mathrm{v}$ tomto případě napomohla zejména odlišení např. citací v souhrnu předchozího řízení a citací v argumentační části. Dále na základě předpokladu, že se soudci v soudních rozhodnutí vypořádávají s právními otázkami obvykle postupně by pak přesná tematická segmentace rozhodnutí dokázala i rozpoznat s určitou pravděpodobností, proč je dané rozhodnutí citováno dle tematického segmentu, ve kterém se citace nachází, a takto by bylo možné klasifikovat citace do tematických okruhů, minimálním standardním rozdělením by $\mathrm{v}$ takovém případě mohlo být oddělení citací procesně a hmotněprávních. Tematická klasifikace byla lehce dotčena v části Textová sítová analýza v souvislosti s analýzou shlukovou, tematická klasifikace bývá nejčastěji spojována s metodami modelování témat a tyto poté bývají často kombinovány právě se shlukovou analýzou. Při dostatečně přesném odlišení tematických celků v rámci rozhodnutí si pak lze představit návrhový systém související judikatury založený na vzájemné citaci a vzájemné příslušnosti ke stejnému tematickému celku.

${ }^{89}$ Nejedná se o novou myšlenku, citace samozřejmě k návrhům souvisejících rozhodnutí bývají často $\mathrm{v}$ praxi využívány, byt $\mathrm{v}$ dále nezpracované podobě. 
Problematické v tomto ohledu je to, že metody modelování témat obecně nevykazují příliš přesné výsledky - ne dostatečně přesné pro klasifikaci právních témat či otázek v rámci jednoho rozhodnutí. Zatím byly tyto metody úspěšně využity pouze $\mathrm{k}$ obecnému zhodnocení právního tématu či ještě obecněji právní oblasti, které se týkají. To je určitě dobrý výchozí bod a automatická klasifikace soudních rozhodnutí dle oblastí má při vyhledávání právních informací svoji roli a svůj smysl. Nicméně pro větší detailnost a přesnost výsledků je spíše nutné jít až na úroveň jednotlivých částí rozhodnutí či odstavců a využít tak přesnějších metod. V takové situaci se nabízí některá z metod sémantické podobnosti dokumentů v kombinaci s automatickou segmentací dokumentu na dílčí části. Metody sémantické podobnosti obecně vykazují velmi přesné výsledky a to zejména v případě velkých datových korpusů, jimiž datasety soudních rozhodnutí bývají. Tyto metody mají potenciál výrazně zpřesnit tvorbu vzájemných vztahů mezi rozhodnutími na základě jak citace tak modelování témat, at už při užití na dílčí části či celá rozhodnutí.

Metody sítové a shlukové analýzy mají ještě jednou významnou výhodu oproti ostatním metodám, kterou je jejich grafický základ. Vizuální a grafický doprovod aplikace metod je logicky předpokládán už jen díky tomu, že tyto metody jsou založené na teorii grafi̊. Vizualizace (právních) dat je určitě metodou zpracování a vyhledávání informací 21. století. Je prokázáno, že zobrazovací metody jsou z hlediska kognitivní uchopitelnosti velkého množství informací pro člověka efektivnější. V tomto směru autorka spatřuje nejsilnější stránku. Nejen, že je možné mezi právními prameny nalézt vztahy, které nemusí být patrné na první pohled, ale navíc na základě těchto vztahů je možné právní prameny zobrazovat v síti a tím snížit kognitivní náročnost dílčích úkolů ve vyhledávání právních pramenů. Opět se nejedná o originální nápad autorky - rekomendační systém založený na sítové analýze „pouhých“ citací navrhnuli již autoři jedné zmiňované studie. ${ }^{90}$ Představení výsledků vyhledávání právních informací formou sítě či grafu výrazně zjednodušuje jejich uchopení a to zejména ve vzájemném kontextu. Jak bylo uvedeno v úvodu této práce, přehled aplikace metod sí-

${ }_{90}$ Case Law App. Dostupné z: https://www.research-software.nl/software/case-law-app. 
tové analýzy zde byl uveden zejména proto, aby byla diskutována vhodnost těchto metod pro vyhledávání a získávání právních informací. Za tímto účelem byly definovány dvě podmínky, které by metody měly splňovat proto, aby byly využitelné $\mathrm{k}$ tomuto cíli - 1) správnost a 2) př́istupnost a kognitivní poznatelnost.

Správnost obsažených právních informací pak souvisí zejména s kanálem, kterým jsou informace získávány a jakým způsobem. V tomto ohledu se tyto metody neliší od ostatních a jsou plně závislé na poskytnutí právních informací státem, a to i na způsobu poskytnutí těchto informací a jejich formátu. Zajímavá je ovšem druhá podmínka a její splnění pomocí těchto metod. Autorka se domnívá, že jejich splnění spočívá výhradně $\mathrm{v}$ přesnosti těchto metod vůči uživatelskému dotazu a poté ve způsobu podání výsledků uživateli. Přesnost metod vyhledávání informací se měří pomocí objektivně určených proměnných a v rámci evaluačních experimentů uživatelů. Variace zmíněných metod se poté samozřejmě projevuje i v různě úspěšných výsledcích $\mathrm{v}$ rámci evaluačních experimentů, autorka však má za to, že kombinace či vrstvení metod za sebe, jak je navrhnuto výše, zaručí dosažení dostatečně přesných výsledků tak, aby byly pro uživatele hodnotné, jakkoliv je nyní tento závěr vágní. Způsob podání výsledků a jejich kognitivní poznatelnost uživatelem je dle autorky podpořen možnou vizualizací informací a jejich grafickým zpracováním, které je méně náročné a efektivnější pro chápání informací v kontextu.

\section{ZÁVĚR}

Autorka si v této práci zvolila dva cíle - přinést přehled metod užití sítové analýzy $\mathrm{v}$ právu a diskutovat jejich použitelnost pro vyhledávání právních informací. Z uvedeného přehledu vyplývá, že dosud jsou sítová analýza a jí blízké metody, jako je shluková analýza, užívány především za účelem zjištování nových informací o fungování práva či jeho jednotlivých institutů a to ve vzájemném kontextu. Za tímto účelem byla provedena velká většina souvisejících výzkumů. Autorka se nicméně domnívá, že tyto metody mají svůj smysl i na poli vyhledávání a získávání právních informací. V závěrečné kapitole tedy navrhuje konkrétní př́istupy v aplikaci metod 
sítové analýzy v kombinaci s ostatními metodami přirozeného zpracování jazyka, kterými by mohlo být dosaženo efektivnějšího vyhledávání právních informací a tím by mohla být naplněna povinnost zpřístupnění obsahu platného práva společnosti na úrovni, kterou předpokládá 21. století.

\section{REFERENCE}

[1] ALBERT, M. B., D. AVERY, F. NARIN a P. MCALLISTER. Direct validation of citation counts as indicators of industrially important patents. Research Policy [online]. 20(3), 1991, s. 251-259. ISSN 0048-7333. Dostupné z: doi:10.1016/0048-7333(91)90055-U.

[2] ASHLEY, Kevin D. Artificial Intelligence and Legal Analytics: New Tools for Law Practice in the Digital Age. Cambridge: Cambridge University Press, 2017. ISBN 978-1-107-17150-3. DOI: $10.1017 / 9781316761380$.

[3] ATHEY, Nicholas C. a Martin BOUCHARD. The BALCO scandal: the social structure of a steroid distribution network. Global Crime. 14(2-3), 2013, s. 216-237. ISSN 1744-0572.

[4] BOMMARITO, Michael J. a Daniel M. KATZ, 2010. A mathematical approach to the study of the United States Code. Physica A: Statistical Mechanics and its Applications [online]. 389(19), 4195-4200. ISSN 0378-4371. Dostupné z: doi:10.1016/j.physa.2010.05.057.

[5] BOUCHARD, Martin et al. Criminal Careers in Cyberspace: Examining Website Failure within Child Exploitation Networks. Justice Quarterly: Vol 33, No 7 [online]. Dostupné z: https://www.tandfonline.com/doi/full/10.1080/07418825.2015.1046393.

[6] BOULET, Romain, Pierre MAZZEGA a Daniele BOURCIER, 2011. A network approach to the French system of legal codes-part I: analysis of a dense network. Artificial Intelligence and Law. 19(4), 333-355.

[7] BOULET, Romain, Pierre MAZZEGA a Danièle BOURCIER, 2018. Network approach to the French system of legal codes part II: the role of the weights in a network. Artificial Intelligence and Law. 26(1), 23-47.

[8] BRADLEY, Robert E. a C. Edward SANDIFER. Leonhard Euler: Life, Work and Legacy. Amsterdam: Elsevier, 2007, 534 s. ISBN 978-0-444-52728-8.

[9] BRANDES, Ulrik. Network Analysis: Methodological Foundations. Springer Science \& Business Media, 2005. ISBN 978-3-540-24979-5.

[10] CALDARELLI, Guido et al. A Network Analysis of Countries' Export Flows: Firm Grounds for the Building Blocks of the Economy. PLOS ONE. 2012, roč. 7, č. 10, s. e47278. ISSN 19326203. DOI: 10.1371/journal.pone.0047278.

[11] CARLUCCI, Lucia, CIANI, Gianfranco a Davide M. PROSERPIO. Polycatenation, polythreading and polyknotting in coordination network chemistry. Coordination Chemistry Reviews, 2003, sv. 246, č. 1-2, s. 247-289. 
[12] CARRINGTON, Peter J., John SCOTT a Stanley WASSERMAN, eds. Models and Methods in Social Network Analysis. Cambridge: Cambridge University Press, 2005. Structural Analysis in the Social Sciences. ISBN 978-0-521-80959-7. DOI: 10.1017/CBO9780511811395.

[13] CLARK, Tom S. a Benjamin E. LAUDERDALE. The Genealogy of Law. Political Analysis. Cambridge University Press, 2012, roč. 20, č. 3, s. 329-350. ISSN 1047-1987, 1476-4989. DOI: $10.1093 / \mathrm{pan} / \mathrm{mps} 019$.

[14] CONRAD, Jack G., Khalid AL-KOFAHI, Ying ZHAO a George KARYPIS, 2005. Effective document clustering for large heterogeneous law firm collections. In: Proceedings of the 10th international conference on Artificial intelligence and law [online]. New York, NY, USA: Association for Computing Machinery, s. 177-187 [vid. 2021-01-10]. ICAIL '05. ISBN 978-1-59593-081-1. Dostupné z: doi:10.1145/1165485.1165513.

[15] COOK, K. S. a J. M. WHITMEYER. Two Approaches to Social Structure: Exchange Theory and Network Analysis. Annual Review of Sociology. 1992, roč. 18, č. 1, s. 109-127. DOI: 10.1146/annurev.so.18.080192.000545.

[16] CROSS, Frank B. a kol. Citations in the U.S. Supreme Court: an Empirical Study of Their Use and Significance. University Illinois Law Review. No. 2, 2010, s. 491. Dostupné z: http://illinoislawreview.org/wp-content/ilr-content/articles/2010/2/Cross.pdf.

[17] DAHLIN, Kristina, Margaret TAYLOR a Mark FICHMAN. Today's Edisons or weekend hobbyists: technical merit and success of inventions by independent inventors. Research Policy [online]. 33(8), 2004, s. 1167-1183. ISSN 0048-7333. Dostupné z: doi:10.1016/ j.respol.2004.06.003.

[18] DE NOOY, Wouter, Andrej MRVAR a Vladimir BATAGELJ. Exploratory Social Network Analysis with Pajek: Revised and Expanded Edition for Updated Software. 3. vyd. Cambridge: Cambridge University Press, 2018. Structural Analysis in the Social Sciences. ISBN 978-1-10847414-6. DOI: 10.1017/9781108565691.

[19] DEGENNE, Alain a Michel FORSÉ. Introducing Social Networks. London: SAGE Publications, 1999, 256 s. ISBN 0761956034.

[20] DERLÉN, Mattias a Johan LINDHOLM, 2015. Characteristics of Precedent: The Case Law of the European Court of Justice in Three Dimensions [online]. SSRN Scholarly Paper ID 2677555. Rochester, NY: Social Science Research Network [vid. 2018-10-23]. Dostupné z: https:// papers.ssrn.com/abstract $=2677555$.

[21] DERLÉN, Mattias a Johan LINDHOLM, 2017. Is it Good Law? Network Analysis and the CJEU's Internal Market Jurisprudence. Journal of International Economic Law [online]. 20(2), 257-277. ISSN 1369-3034, 1464-3758. Dostupné z: doi:10.1093/jiel/jgx011.

[22] DICKEN, Peter et al. Chains and networks, territories and scales: towards a relational framework for analysing the global economy. Global Networks. 2001, roč. 1, č. 2, s. 89-112. ISSN 1471-0374. DOI: 10.1111/1471-0374.00007.

[23] EMIRBAYER, Mustafa a Jeff GOODWIN. Network Analysis, Culture, and the Problem of Agency. American Journal of Sociology. 1994, roč. 99, č. 6, s. 1411-1454. ISSN 0002-9602. DOI: $10.1086 / 230450$. 
[24] FARLEY, Jonathan David. Breaking Al Qaeda Cells: A Mathematical Analysis of Counterterrorism Operations (A Guide for Risk Assessment and Decision Making). Studies in Conflict \& Terrorism: Vol 26, No 6 [online]. Dostupné z: https://www.tandfonline.com/doi/abs/ $10.1080 / 10576100390242857$.

[25] FLEMING, Lee a Olav SORENSON. Technology as a complex adaptive system: evidence from patent data. Research Policy [online]. 30(7), 2001, s. 1019-1039. ISSN 0048-7333. Dostupné z: doi:10.1016/S0048-7333(00)00135-9.

[26] FOWLER, James H. a Sangick JEON. The authority of Supreme Court precedent. Social Networks [online]. 30(1), 16-30, 2008. ISSN 03788733. Dostupné z: doi:10.1016/ j.socnet.2007.05.001.

[27] FOWLER, James H., Timothy R. JOHNSON, James F. SPRIGGS, Sangick JEON a Paul J. WAHLBECK. Network Analysis and the Law: Measuring the Legal Importance of Precedents at the U.S. Supreme Court. Political Analysis [online]. 15(3), 324-346, 2007. ISSN 1047-1987, 1476-4989. Dostupné z: doi:10.1093/pan/mpm011.

[28] GARFIELD, Eugene. Citation Indexing: Its Theory and Application in Science, Technology, and Humanities. B.m.: Isi Press, 1979, s. 37 - 40. ISBN 978-0-89495-024-7.

[29] GEIST, Anton. The Open Revolution: Using Citation Analysis to Improve Legal Text Retrieval. European Journal of Legal Studies. 2008, roč. 2, č. 3, s. 137-145.

[30] GEIST, Anton. Using Citation Analysis Techniques For Computer-Assisted Legal Research in Continental Jurisdictions, Graduate thesis, University of Edinburgh, 2009. Available at: http// papers.ssrn.com/sol3/Delivery.cfm/SSRNID1397674_codelO87080.pdf?abstractid = 1 $397674 \&$ mirid $=1$.

[31] GÓRSKI, Lukasz. Towards Legal Change Analysis: Clustering of Polish Civil Code Amendments [online]. CEUR-WS.org, 2019. CEUR Workshop Proceedings. Dostupné z: http://ceurws.org/Vol-2385/paper11.pdf.

[32] GRANOVETTER, Mark. Social Structures: A Network Approach. In: WELLMAN, Barry a BERKOWITZ, S. D. (eds.). Structural Analysis in the Social Sciences, vol. 2. Cambridge: Cambridge University Press, 1988, 513 s. ISBN 9780521286879.

[33] HARAŠTA, Jakub, Terezie SMEJKALOVÁ, Tereza NOVOTNÁ, Jaromír ŠAVELKA, Radim POLČÁK, František KASL, Pavel LOUTOCKÝ a Jakub MÍŠEK. Citační analýza judikatury. 1. vydání. Praha: Wolters Kluwer, 2021. 256 s. Právní monografie. ISBN 978-80-7598-749-5.

[34] HARAŠTA, Jakub. Srovnávací studie právních informačních systémů: rozdíly mezi systémy při využití různých vyhledávacích strategií. Revue pro právo a technologie. Masarykova univerzita, 2020, roč. 11, č. 22, s. 219-260. ISSN 1804-5383. doi:10.5817/RPT2020-2-8.

[35] HEINZ, John P. a Edward O. LAUMANN. Chicago Lawyers: The Social Structure of the Bar [online]. Russell Sage Foundation, 1982 [cit. 06.10.2021]. ISBN 978-0-87154-378-3. Dostupné z: https://www.jstor.org/stable/10.7758/9781610442848.

[36] HEINZ, John P., Edward O. LAUMANN a Robert L. NELSON. The Hollow Core: Private Interests in National Policy Making. Harvard University Press, 1993. ISBN 978-0-674-40525-7. 
[37] HORVATH, Steve. Weighted Network Analysis: Applications in Genomics and Systems Biology. New York: Springer-Verlag, 2011. ISBN 978-1-4419-8818-8. DOI: 10.1007/978-1-44198819-5.

[38] KAHLER, Miles. Networked Politics: Agency, Power, and Governance. Cornell University Press, 2011. ISBN 978-0-8014-5764-7.

[39] KATZ, Daniel M. a Derek K. STAFFORD. Hustle and Flow: A Social Network Analysis of the American Federal Judiciary. Ohio State Law Journal. 2010, č. 3, s. 457-510.

[40] KIPLING, Airlin L. a Michael THOMPSON. Network Analysis Methods Applied to Liquid-phase Acoustic Wace Sensors. Analytical Chemistry, 1990, roč. 62, č. 14, s. 1514-1519.

[41] KONIARIS, Marios, Ioannis ANAGNOSTOPOULOS a Yannis VASSILIOU, 2017. Network Analysis in the Legal Domain: A complex model for European Union legal sources. Journal of Complex Networks. 6(2), 243-268.

[42] KUMAR, Ravi V. and RAGHUVEER, K. Legal Documents Clustering using Latent Dirichlet Allocation. International Journal of Applied Information Systems. 2(6):27-33, 2012.

[43] KUPPEVELT, Dafne VAN a Gijs VAN DIJCK, 2017. Answering Legal Research Questions About Dutch Case Law with Network Analysis and Visualization. In: Legal Knowledge and Information Systems: JURIX 2017: The Thirtieth Annual Conference. B.m.: IOS Press, s. 95.

[44] LAZEGA, Emmanuel a Marijtje VAN DUIJN. Position in formal structure, personal characteristics and choices of advisors in a law firm: A logistic regression model for dyadic network data. Social Networks. 1997, roč. 19, č. 4, s. 375-397. ISSN 0378-8733. DOI: 10.1016/S0378-8733(97)00006-3.

[45] LAZEGA, Emmanuel. The Collegial Phenomenon: The Social Mechanisms of Cooperation Among Peers in a Corporate Law Partnership. Oxford: Oxford University Press, 2001. ISBN 9780-19-924272-6. DOI: 10.1093/acprof:oso/9780199242726.001.0001.

[46] LEIFELD, Philip. Reconceptualizing Major Policy Change in the Advocacy Coalition Framework: A Discourse Network Analysis of German Pension Politics. Policy Studies Journal. 2013, roč. 41, č. 1, s. 169-198. ISSN 1541-0072. DOI: 10.1111/psj.12007.

[47] LEIGHTON, Barry. The Community Concept in Criminology: Toward a Social Network Approach. Journal of Research in Crime and Delinquency [online]. 25(4), s. 351-374, 1988. ISSN 0022-4278. Dostupné z: doi:10.1177/0022427888025004003.

[48] LINCOLN, James R., Michael L. GERLACH a Peggy TAKAHASHI. Keiretsu Networks in the Japanese Economy: A Dyad Analysis of Intercorporate Ties. American Sociological Review [JSTOR]. 1992, roč. 57, č. 5, s. 561-585. ISSN 0003-1224. DOI: 10.2307/2095913.

[49] LU, Qiang, Jack G. CONRAD, Khalid AL-KOFAHI a William KEENAN, 2011. Legal document clustering with built-in topic segmentation. In: the 20th ACM international conference: Proceedings of the 20th ACM international conference on Information and knowledge management CIKM '11 [online]. Glasgow, Scotland, UK: ACM Press, s. 383 [vid. 2021-01-09]. ISBN 978-14503-0717-8. Dostupné z: doi:10.1145/2063576.2063636. 
[50] MALMGREN, Staffan. Towards a theory of jurisprudential relevance ranking. Using Link Analysis on EU Case Law. Graduate thesis, Stockholm University, 2011, 116 s.

[51] MARX, Stephen M. Citation Networks in the Law. Jurimetrics Journal. Vol. 10, 1979, s. 121-137.

[52] MERKL D. and SCHWEIGHOFER, Erich. En route to data mining in legal text corpora: Clustering, neural computation, and international treaties. In Proceedings of the 8th International Workshop on Database and Expert Systems Applications (DEXA '97), 1997.

[53] MORSELLI, Carlo, Cynthia GIGUÈRE a Katia PETIT. The efficiency/security trade-off in criminal networks. Social Networks [online]. 29(1), 2007, s. 143-153. ISSN 0378-8733. Dostupné z: doi:10.1016/j.socnet.2006.05.001.

[54] NANDA, Rohan et al. Legal Information Retrieval Using Topic Clustering and Neural Networks [online]. In: Proceedings of COLIEE 2017. EPiC Series in Computing. Dostupné z: http://www.easychair.org/publications/paper/347228.

[55] NASH, Rebecca, Martin BOUCHARD a Aili MALM. Investing in people: The role of social networks in the diffusion of a large-scale fraud. Social Networks [online]. 35(4), 2013, s. 686698. ISSN 0378-8733. Dostupné z: doi:10.1016/j.socnet.2013.06.005.

[56] NEALE, Thom. Citation Analysis of Canadian Case Law. Journal of Open Access to Law. 2013, roč. 1, s. 1-60.

[57] NEALE, Thom. Citation Analysis of Canadian Case Law. Journal of Open Access to Law. 2013, roč. 1, s. 1-60.

[58] OCELÍK, Petr et al. A contested transition toward a coal-free future: Advocacy coalitions and coal policy in the Czech Republic. Energy Research \& Social Science. 2019, roč. 58, s. 101283. ISSN 2214-6296. DOI: 10.1016/j.erss.2019.101283.

[59] OTTE, Evelien a Ronald ROUSSEAU. Social network analysis: a powerful strategy, also for the information sciences. Journal of Information Science. 2002, roč. 28, č. 6, s. 441-453. ISSN 0165-5515. DOI: 10.1177/016555150202800601.

[60] PANAGIS, Yannis, Urska SADL a Fabien TARISSAN, 2017. Giving every case its (legal) due The contribution of citation networks and text similarity techniques to legal studies of European Union law. In: 30th International Conference on Legal Knowledge and Information Systems (JURIX'17). B.m.: IOS Press, s. 59-68.

[61] POLČÁK, Radim. Internet a proměny práva. 1. vyd. Praha: Auditorium, 2012, 388 s. ISBN 978-80-87284-22-3.

[62] POUDYAL, Prakash, Teresa GONÇALVES a Paulo QUARESMA. Using Clustering Techniques to Identify Arguments in Legal Documents [online]. In: CEUR Workshop Proceedings, 2019. Dostupné z: http://ceur-ws.org/Vol-2385/paper2.pdf.

[63] RÜCKER, Gerta. Network meta $\neg$ analysis, electrical networks and graph theory. Research Synthesis Methods, 2012, roč. 3, č. 4, s. 312-324.

[64] SCOTT, John. Social Network Analysis. 4th Edition. Los Angeles: SAGE Publications, 2017, 248 s. ISBN: 9781473952126. 
[65] SCOTT, John. TREND REPORT SOCIAL NETWORK ANALYSIS. Sociology [JSTOR]. 1988, roč. 22, č. 1, s. 109-127. ISSN 0038-0385.

[66] SMITH, David A. a Douglas R. WHITE. Structure and Dynamics of the Global Economy: Network Analysis of International Trade 1965-1980. Social Forces. 1992, roč. 70, č. 4, s. 857893. ISSN 0037-7732. DOI: 10.1093/sf/70.4.857.

[67] SMITH, Thomas A. The Web of Law. San Diego Legal Studies Research. Paper No. 06-11, 2005. Available at http://papers.ssrn.com/sol3/papers.cfmabstract-id $=642863$.

[68] SUSSKIND, Richard E. The Future of Law: Facing the Challenges of Information Technology. Oxford: Clarendon Press, 1998, 309 s. ISBN 978-0-19-876496-0.

[69] TAPPER, Colin. The Use of Citation Vectors for Legal Information Retrieval. Journal of Law \& Information Science. Vol. 1, No. 2, 1981, s. 131- 161.

[70] TIAN, Xin et al. K-Means Clustering for Controversial Issues Merging in Chinese Legal Texts. Legal Knowledge and Information Systems. IOS Press, 2018, s. 215-219. DOI: 10.3233/978-1-61499-935-5-215

[71] UZZI, Brian a Ryon LANCASTER. Embeddedness and Price Formation in the Corporate Law Market. American Sociological Review. SAGE Publications Inc, 2004, roč. 69, č. 3, s. 319344. ISSN 0003-1224. DOI: 10.1177/000312240406900301.

[72] VAN OPIJNEN, Marc a Cristiana SANTOS. On the concept of relevance in legal information retrieval. Artificial Intelligence and Law. 2017, roč. 25, č. 1, s. 65-87. ISSN 1572-8382. DOI: 10.1007/s10506-017-9195-8.

[73] VAN OPIJNEN, Marc. A model for automated rating of case law. In: Proceedings of the ICAIL '13, Rome, Italy: ACM Press, 2013. ISBN 978-1-4503-2080-1. DOI: $10.1145 / 2514601.2514617$.

[74] VENKATESH, Ravi kumar. Legal Documents Clustering and Summarization using Hierarchical Latent Dirichlet Allocation. IAES International Journal of Artificial Intelligence (IJ-AI). 2013, roč. 2, č. 1, s. 27-35. ISSN 2252-8938.

[75] WAGH, R. a D. ANAND, 2017. Application of citation network analysis for improved similarity index estimation of legal case documents: A study. In: 2017 IEEE International Conference on Current Trends in Advanced Computing (ICCTAC): 2017 IEEE International Conference on Current Trends in Advanced Computing (ICCTAC) [online]. s. 1-5. Dostupné z: doi:10.1109/ ICCTAC.2017.8249996.

[76] WASSERMAN, Stanley a Katherine FAUST. Social Network Analysis: Methods and Applications. Cambridge: Cambridge University Press, 1994, 825 s. ISBN 9780521387071.

[77] WATTS, Duncan J. Six Degress: the Science of Connected Age. New York: W. W. Norton \& Company, 2003, 368 s. ISBN 9780099444961.

[78] WHALEN, Ryan. Legal Networks: The Promises and Challenges of Legal Network Analysis. Michigan State Law Review. 2016, roč. 2016, s. 539. 
[79] WHALEN, Ryan. Modeling Annual Supreme Court Influence: The Role of Citation Practices and Judicial Tenure in Determining Precedent Network Growth. In: Ronaldo MENEZES, Alexandre EVSUKOFF a Marta C. GONZÁLEZ, ed. Complex Networks [online]. Berlin, Heidelberg: Springer Berlin Heidelberg, Studies in Computational Intelligence, s. 169-176, 2013 [vid. 2019-10-06]. ISBN 978-3-642-30287-9. Dostupné z: doi:10.1007/978-3-642-30287-9_18.

[80] WINKELS, Radboud, Jelle RUYTER a Henryk KROESE. Determining Authority of Dutch Case Law [online]. SSRN Scholarly Paper ID 2013190. Rochester, NY: Social Science Research Network, 2011. Dostupné z: https://papers.ssrn.com/abstract $=2013190$.

[81] WOLFE, Alvin W. Anthropologist view of social network analysis and data mining. Social Network Analysis and Mining. 2011, roč. 1, č. 1, s. 3-19. ISSN 1869-5469. DOI: 10.1007/ s13278-010-0014-4.

[82] WOLFE, Alvin W. The rise of network thinking in anthropology. Social Networks. 1978, roč. 1, č. 1, s. 53-64. ISSN 0378-8733. DOI: 10.1016/0378-8733(78)90012-6.

Toto dílo lze užít v souladu s licenčními podmínkami Creative Commons BY-SA 4.0 International (http://creativecommons.org/licenses/by-sa/4.0/legalcode). 